\title{
Catherine's Icon: Pavel Filonov and the Orthodox World
}

\author{
Nicoletta Misler ${ }^{1}$ and John E. Bowlt ${ }^{2, *}$ \\ 1 Dipartimento di Slavistica, Istituto Universitario “L'Orientale”, 80133 Naples, Italy; mislern@gmail.com \\ 2 Department of Slavic Languages, University of Southern California, Los Angeles, CA 90007, USA \\ * Correspondence: bowlt@usc.edu
}

check for

updates

Citation: Misler, Nicoletta, and John E. Bowlt. 2021. Catherine's Icon: Pavel Filonov and the Orthodox World. Religions 12: 502. https:// doi.org/10.3390/rel12070502

Academic Editor: Dennis Ioffe

Received: 3 June 2021

Accepted: 29 June 2021

Published: 6 July 2021

Publisher's Note: MDPI stays neutral with regard to jurisdictional claims in published maps and institutional affiliations.

Copyright: (c) 2021 by the authors. Licensee MDPI, Basel, Switzerland. This article is an open access article distributed under the terms and conditions of the Creative Commons Attribution (CC BY) license (https:// creativecommons.org/licenses/by/ $4.0 /)$.

\begin{abstract}
The authors discuss the Orthodox icon which Pavel Filonov (1883-1941) painted in 1908 or 1909 for his sister, Ekaterina, placing it within the broader context of his oeuvre, his family and his understanding of 'religiosity'. Making reference to Filonov's system of Analytical Art and to what he called 'madness', the authors focus on the particular technical devices which he used in the icon and on the podlinnik (or primer) from which he copied the main elements. Reference is also made to other religious motifs in Filonov's art such as the Magi, Flight into Egypt and Crucifixion.
\end{abstract}

Keywords: Pavel Filonov and his family; icons of St. Catherine the Martyr; Orthodoxy; Old Believers; Imperial Academy of Arts; Crucifixion; Natal'ia Goncharova; Kazimir Malevich; Vladimir Tatlin; Cathedral of the Intercession at Rogozhskaia sloboda (Moscow)

\section{Preamble}

The artist Pavel Nikolaevich Filonov (1883-1941), a primary member of the Russian avant-garde, is remembered for the highly enigmatic paintings and drawings which he executed according to his system of Analytical Art or Madeness. ${ }^{1}$ Although occasionally investigating abstraction, Filonov tended to concentrate on intensely crowded compositions showing numerous heads and figures often languishing in a mysterious and ominous city, compositions striking in their dense stratification and almost microscopic detail. Although, by way of his mysterious subject-matter and 'Expressionist' style, Filonov stands apart from his more familiar colleagues such as Kazimir Malevich and Vladimir Tatlin, there is a single - and unexpected-common denominator which interconnects, i.e., an appreciable debt to the Russian Orthodox or, rather, Christian, tradition. This denominator, however, often manifested itself indirectly or metaphorically, rather than in immediate extrapolations in the sense that Malevich, for example, described the early phase of his artistic evolution as 'iconic', although he never painted icons, Tatlin examined Mediaeval icons such as The Virgin Mary of Vladimir from a purely formal perspective, reducing their compositions to geometric schemes, Natal'ia Goncharova painted saints and apostles, making recourse to Neo-Primitivist and Cubo-Futurist styles and, of course, Vasilii Kandinsky looked to the Old Testament for images of the Flood and the Apocalypse. Still, other salient artists of the avant-garde such as Aleksandra Ekster, Ivan Kliun, Liubov' Popova and Aleksandr Rodchenko seem to have ignored the Christian legacy altogether. In contrast, and more than any other of his radical colleagues, Filonov did focus on the Biblical story, at least during the early part of his career, producing numerous, highly personal interpretations of key episodes such as Flight into Egypt (1918, Figure 1), The Magi (1913, Figure 2), Easter (1912-13, private collection, St. Petersburg) and Holy Family (1913-14, Figure 3). ${ }^{2}$ In particular, in 1908 or 1909 Filonov painted an "image of Catherine the Great Martyr from a figural icon primer" (Figure 4$)^{3}$ for his sister, Ekaterina (perhaps as a wedding present)—or, more probably, from an original which he may have seen in the Cathedral of the Intercession (Pokrovskii sobor) in the Rogozhskaia sloboda, Moscow (Figure 5), and which he seems to have copied almost literally, "toch' $v$ toch'". ${ }^{4}$ The focus of this article is on the wider, familial context of this icon, its accommodation within Filonov's oeuvre and its ultimate 
destiny —and, in general, the difficult issue of Filonov's religious beliefs. ${ }^{5}$ The result is at once a detective story, an archaeological expedition and an art-historical evaluation. ${ }^{6}$

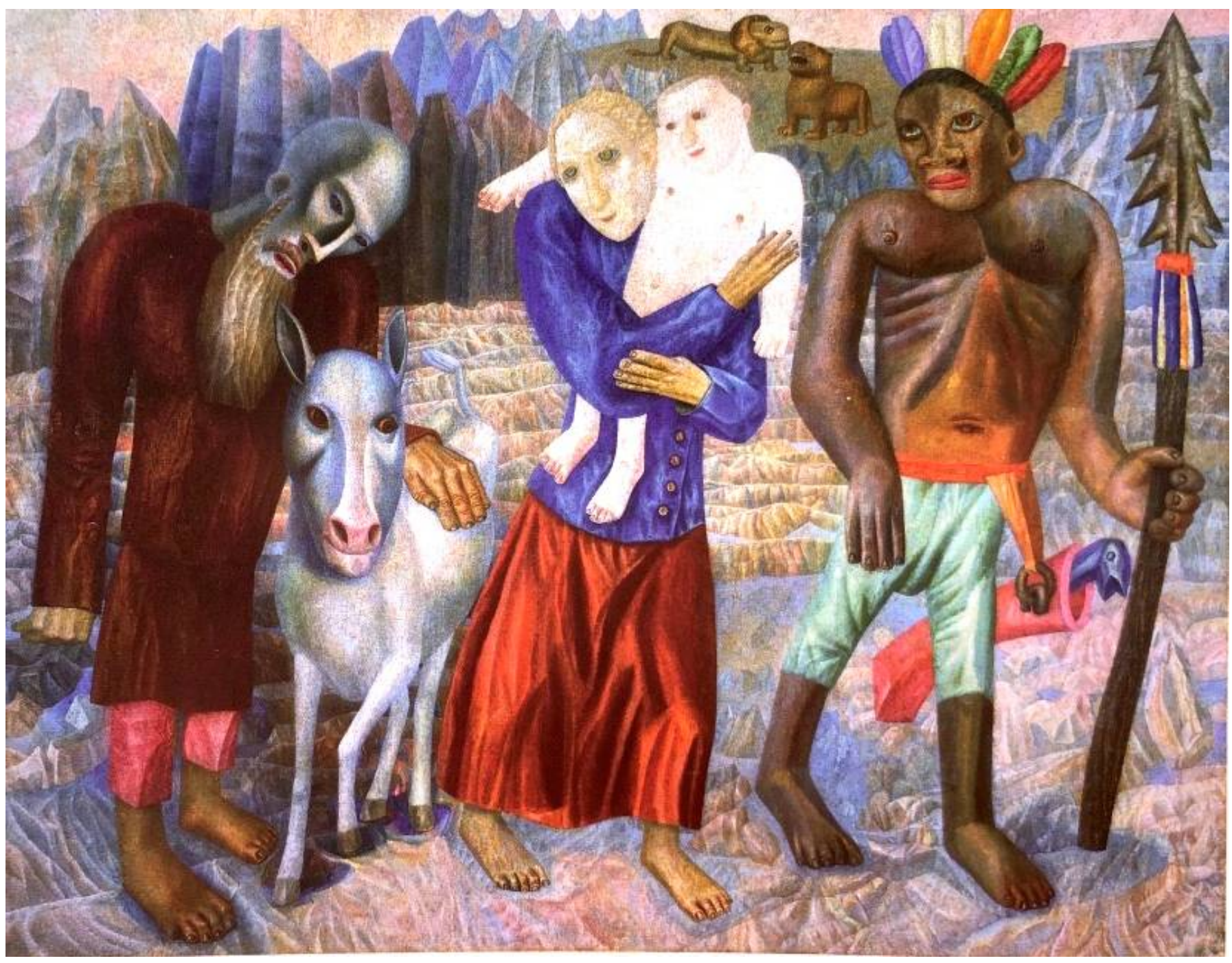

Figure 1. Flight into Egypt (1918, oil on canvas, $71.1 \times 88.9$, Thomas Whitney Collection, Mead Museum, Amherst College, USA). 


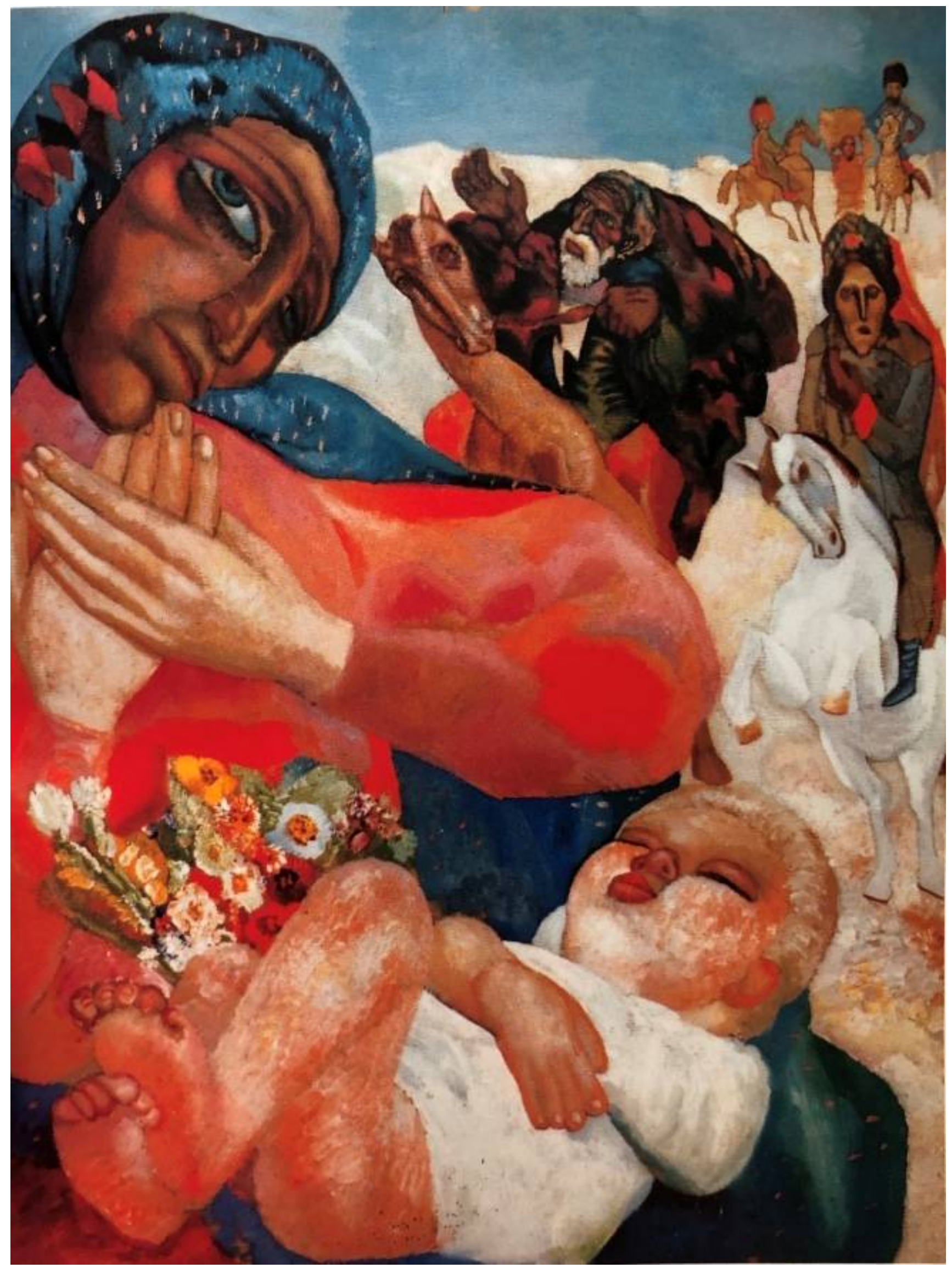

Figure 2. The Magi (Adoration of the Magi) (1913, tempera on paper, $35.5 \times 45.5$, private collection, Switzerland). 


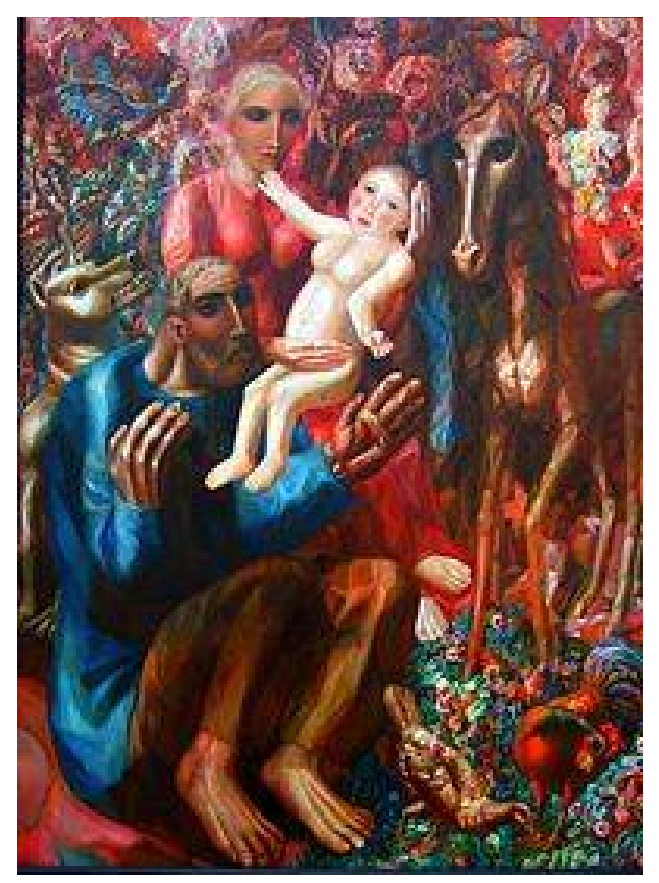

Figure 3. Holy Family (Peasant Family) (1913-14, oil on canvas, $160 \times 117$, State Russian Museum, St. Petersburg; hereafter SRM: Zh 9578).

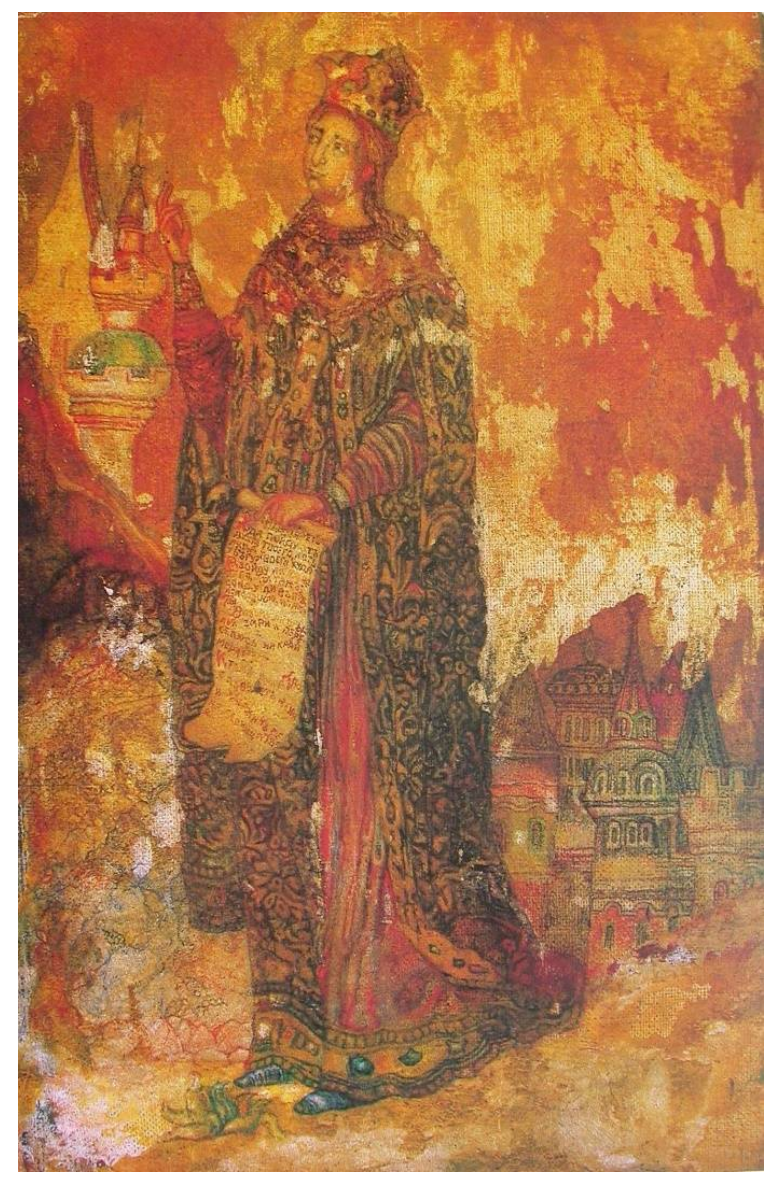

Figure 4. Icon of St. Catherine of Alexandria, the Great Martyr (1908-9, oil on canvas on wood, $27 \times 18$, collection of Mikhail Suslov, Russia). 


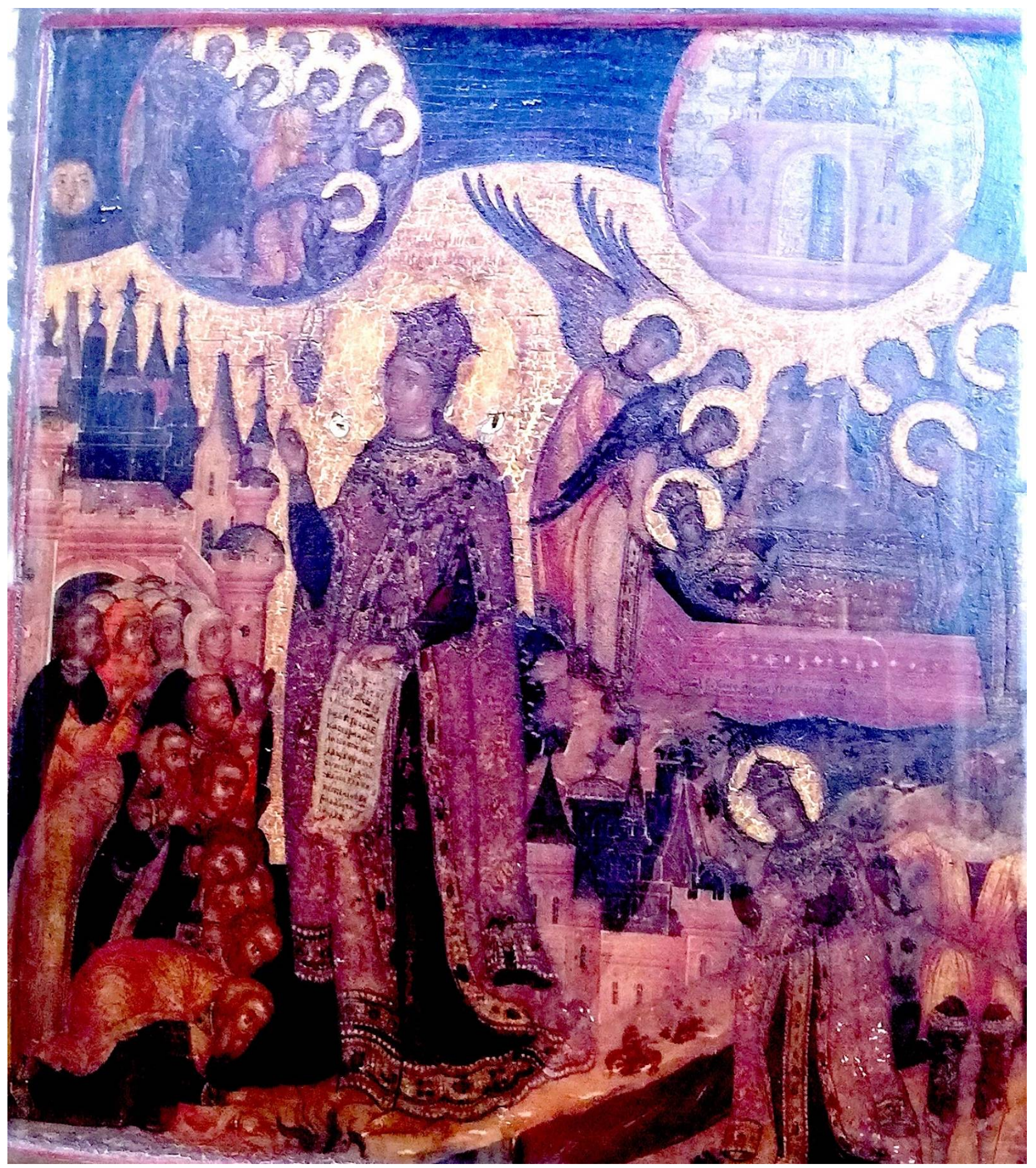

Figure 5. Anon. (Stroganov school): Icon of St. Catherine (17th century, Pokrovskii sobor, Rogozhskaia sloboda, Moscow).

In rendering his illustration of St. Catherine, Filonov was, on the one hand, following the ancient tradition of icon-painting with its hieratic iconography, strict arrangement of figures, colours and perspectives and absence of signature (the icon-painter serving merely as the translator of a divine image and word) - and the fact that Filonov hardly ever signed his own easel paintings might be a gesture to this convention. Obviously, 
Filonov was well aware of the particular and intrinsic elements of the traditional Russian icon-treatment of the wooden board, special ground (levkas), constant and formulaic composition, instructive purpose to the faithful-but in St. Catherine he bypassed or at least emended some of these constituents. Indeed, in his icon Filonov was referring to a comparatively late original, reminiscent not of the Mediaeval canons of Dionysius or Rublev, but of the early 17th century decorative and "worldly" style of Simon Ushakov or Fedor Zubov-an innovation which coincided with the fundamental raskol (schism) within the Orthodox church, Patriarch Nikon calling for strong reforms in liturgy and acts of worship. Those who resisted such innovation came to be known as Old Believers (raskol'niki), a contingent which was especially notable in Riazan', the seat of the Filonov family.

Filonov, however, in removing the icon of St. Catherine from what should have been a cultic purpose to a profane context (a present for his sister), Filonov seems to be supporting the Orthodox reformists and even the bold trend whereby art historians began to consider the Russian icon as a "work of art" rather than as a sacred image, a trend which culminated in Pavel Muratov's laic exhibition of "Ancient Russian Painting" at the Imperial Archaeological Institute in Moscow in 1913. Presumably, Filonov, too, was drawn to the Stroganov St. Catherine more as a "picture" than as an item of devotion and, in any case, he seems not to have been an eager champion of the Orthodox rite with its priesthood, liturgy, iconostasis, holy water, prayers and so on, but rather to have cultivated his own system of religious belief tinged with nuances of pantheism and cosmism. As to whether Filonov or his sister ever entertained the idea of placing his icon in an oklad or precious cover is not known.

Filonov's particular attitude towards the icon coincides with the mutation, if not, crisis, which continued to bait Orthodoxy as an intact institution in the late 19th and early 20th centuries. At this moment of question, doubt and counteraction, leading intellectuals such as Vladimir Solov'ev and Viacheslav Ivanov began to explore alternatives to the severe canon of Greek Orthodoxy, encouraging a more universal, more humanist approach to the church service, the holy calendar and festivals and rituals such as the Eucharist, even proposing that the Orthodox church move closer to Catholicism and Protestantism.

Unfortunately, Filonov's personal testimonies, notes and diaries provide scant information on his early artistic development. Consequently, in attempting to reconstruct Filonov's formative years, the researcher is bound to make recourse to ancillary materials so as to cope with the lacunae and self-censorship of the Stalin period. In this sense, the rediscovery and study of Filonov's Icon of St. Catherine of Alexandria, the Great Martyr (hereafter: Icon of St. Catherine) in 1990 and its inclusion in his retrospective exhibition at the Kunsthalle in Dusseldorf the same year have been fundamental to understanding Filonov's worldview-which, rather than "Christian" or "Orthodox" might be described more broadly as religious, even if, as Nikolai Lozovoi, one of his students, recalled, "Pavel Nikolaevich was not a mystic and was distinguished not by religiosity, but by an overriding belief in the force of the human spirit, in human will-and this was very much part of him. I remember someone saying that, during the course of work paints change their essence beneath the paintbrush. Pavel Nikolaevich supported this strange idea. 'Yes', he said, 'a kind of emanation does take place, but let's not dwell on this, otherwise we'll be accused of vitalism". (Lozovoi 2005, p. 272).

\section{Family Values}

In 1924, perhaps remembering his painting called Easter (1912-13) of a family at table, Filonov painted a group portrait entitled Family Portrait (Easter) (Figure 6). The importance of the picture lies in its representation not only of Filonov's solid, middle-class relatives, but also of the alliance between a patriarchal Russian family and the most important festival in the Orthodox calendar, i.e., Easter (an association which, in Soviet references to the picture was, of course, lost from view). ${ }^{7}$ 
In Family Portrait Filonov included many members of his immediate family (see caption to Figure 6) who can also be identified in the family tree (Figure 7), although outsider and renegade, observer rather than participant, Filonov himself is noticeable by his absence. The composition begs many questions-the almost total absence of side plates and cutlery, the ten individuals with only three cups and three glasses, the vacuum background, the black, 'cut-out' silhouettes surrounding some of the figures-elements which elicit associations with a funerary repast than with a joyous celebration, or perhaps with an altar offering rather than with food for consumption. In any case, the subject of Family Portrait is not simply a group of close individuals, but also a scene common to many of Filonov's paintings and drawings, i.e., of individuals at table, serious and detached, if not, lugubrious, as if observing a venerate ritual, reminiscent of some last and joyless supper as in the celebrated Feast of the Kings (1912-13, SRM), for example.

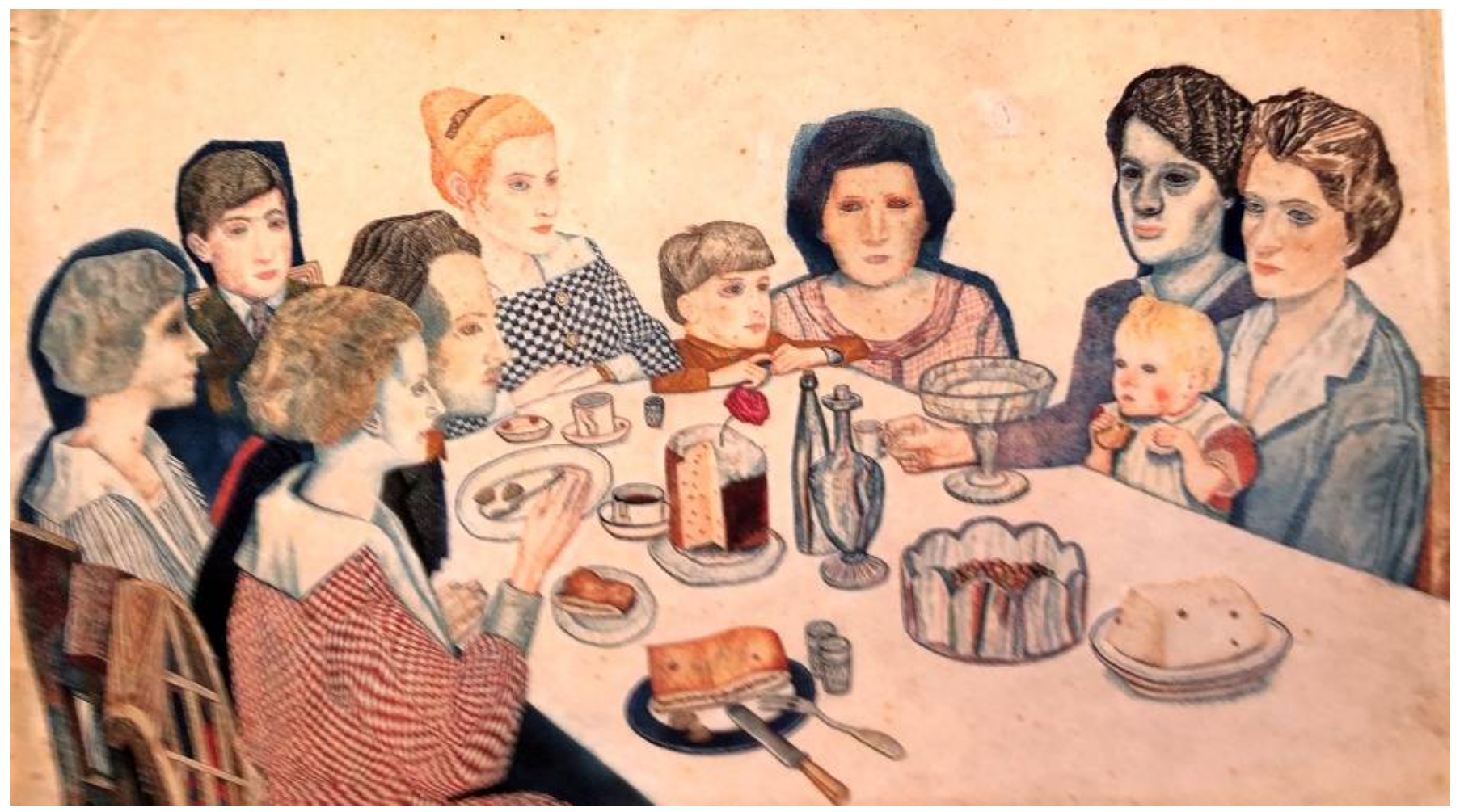

Figure 6. Family Portrait (Easter) (1924, watercolour and pencil on paper, $20.6 \times 52$; SRM: RS 14833). From left to right: Liubov Aleksandrovna Gue (Goué) (daughter of Aleksandr Gue and husband of Aleksandra Nikolaevna Gue, one of Filonov's sisters); Nikolai Nikolaevich Glebov-Putilevsky, husband of Evdokiia Nikolaevna Glebova (Filonov's youngest sister missing here); Mariia Aleksandrovna Emel'antseva (daughter of the Gues); René Armanovich Aziber (son of Filonov's oldest sister, Ekaterina, and her second husband, Arman Aziber [Azibert]); Ekaterina Fokina-Aziber (Filonova); Vladimir Aleksandrovich Gue (son of the Gues); Aleksandra Aleksandrovna Makokina (daughter of the Gues); Mariia Nikolaevna Filonova (another of Filonov's sisters); Aleksandra Nikolaevna Gue (wife of Aleksandr Andreevich Gue); and Makokina's baby daughter, Galina. 


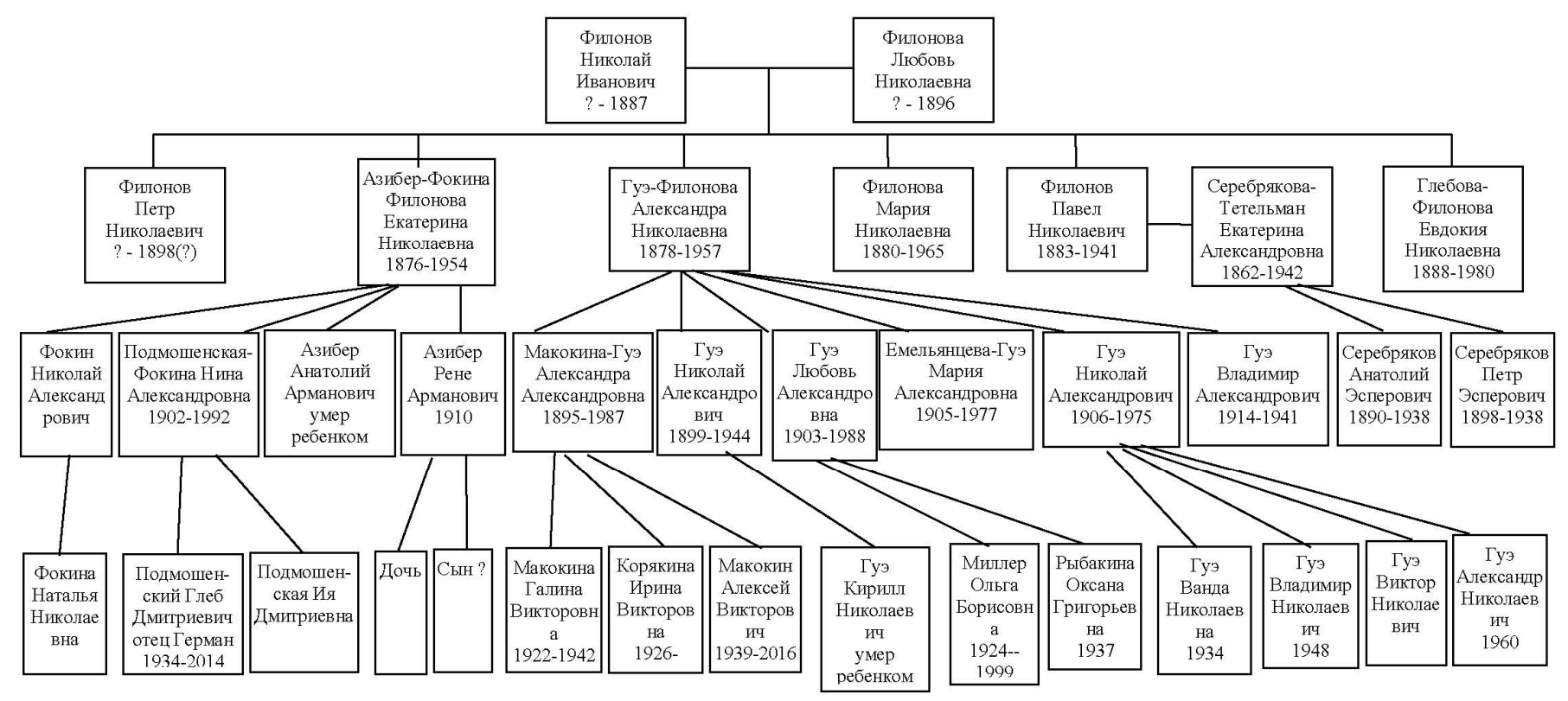

Figure 7. Family tree compiled by Oksana Rybakina, St. Petersburg, 1990.

Of particular relevance to our story is the presence in Family Portrait of Filonov's sister, Ekaterina Nikolaevna Filonova-Fokina (1876-954, Figure 8), seated fifth from left, and her son, René (to her immediate right). The eldest of six children (Nikolai, Aleksandra, Mariia, Pavel and Evdokiia), ${ }^{8}$ in 1900 (?) Ekaterina married Aleksandr Mikhailovich Fokin (1877-937, brother of the celebrated dancer and choreographer Michel Fokine), to whom she bore two children, Nina (in marriage: Nina Podmoshenskaia; abbreviated to Podmo; St. Petersburg, 1901-Platina, CA, USA, 1994; Figure 9) and Nikolai (1905-after 1937). Judging from verbal and visual information, Ekaterina's marriage to Aleksandr granted her entrée into the upper bourgeoisie of St. Petersburg inasmuch as he was a successful businessman, owning a major bicycle store and also, it would seem, at one point, a car dealership. In any case, Fokin was not foreign to the arts, acquiring and managing the Troitskii Theater of Miniatures in St. Petersburg in 1911 as a gift to his second wife, the ballerina and star of the Maryinsky Theater, Aleksandra Aleksandrovna Fedorova (Alexandra Fedorova, 1884-972), even receiving a gold watch from Tsar Nicholas for his production of an operetta at the Winter Palace. ${ }^{9}$ In emigration he continued his theatrical activities, underwriting Fedorova's dancing career in Latvia. That Ekaterina was elegant and solvent is apparent from a photograph of her taken in ca. 1904 and given to us by her grandson (son of Nina Podmo), Abbot Herman (Figure 10), at the conference, "Pavel Filonov: Painter of Metamorphosis", held at the Solomon R. Guggenheim Museum in New York in April, 1983 (Figure 11), a photograph very different from the family photograph taken in Moscow in ca. 1882 where Ekaterina sits dourly on her father's knees (Figure 12). 


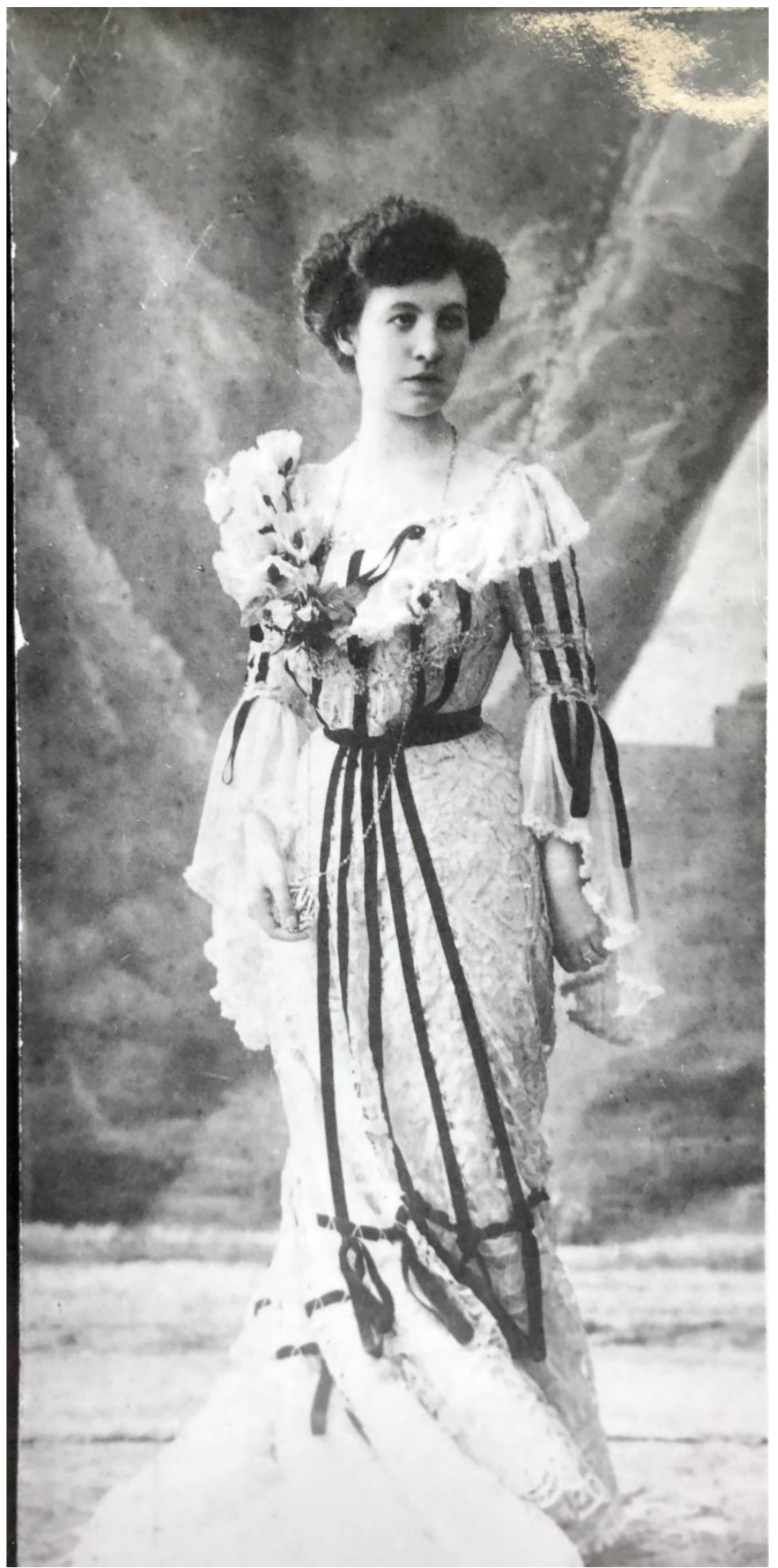

Figure 8. Anon.: Photograph of Ekaterina Nikolaevna Filonova (1876-954; by first marriage: Fokina; by second marriage: Aziber), St. Petersburg, ca. 1904. SRM: Department of Manuscripts. Call No. f. 156, op. 1, ed. khr. 216, 1. 1. 


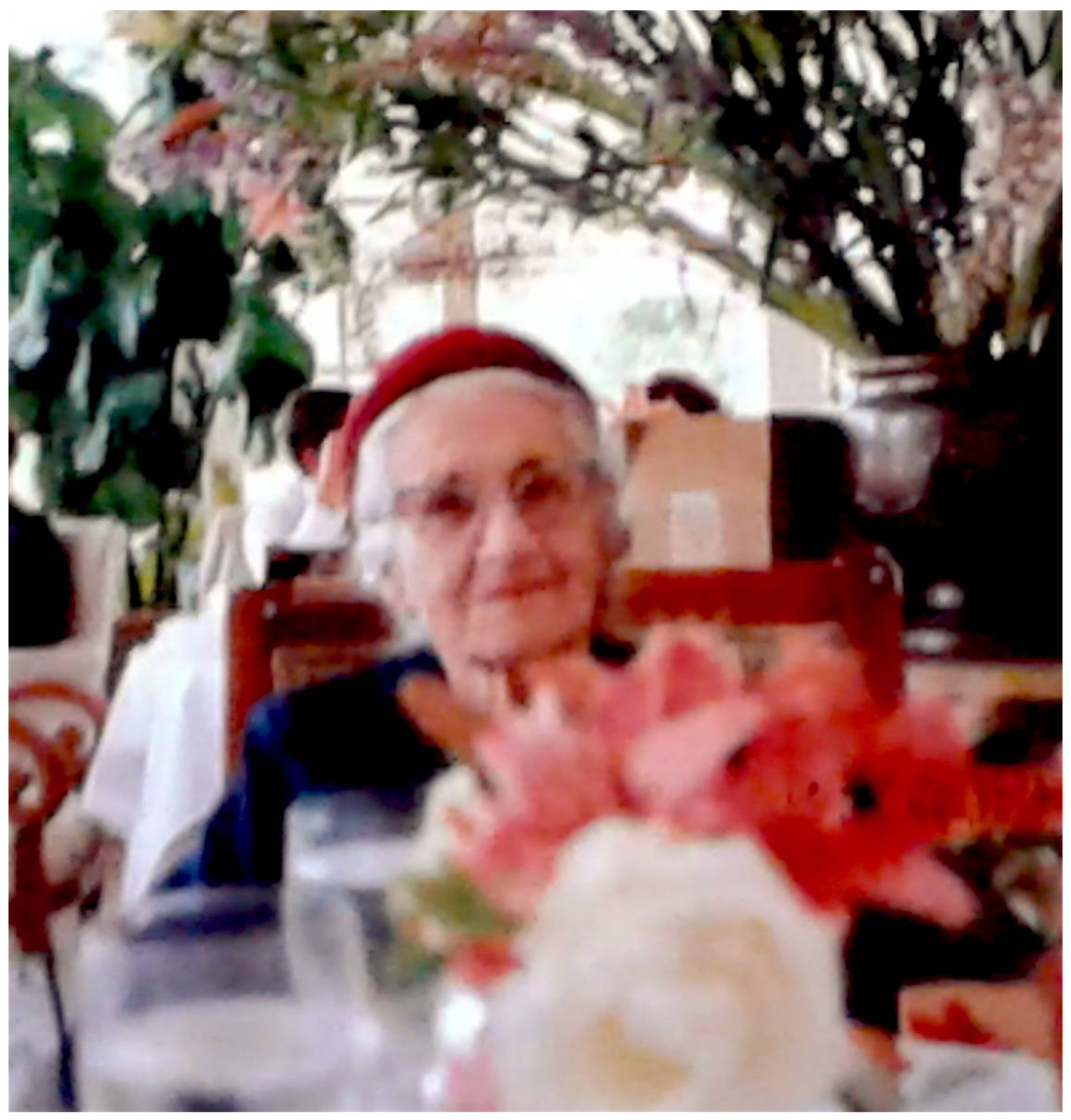

Figure 9. Nicoletta Misler: Photograph of Nina Podmo, Santa Rosa, California, 1989. 


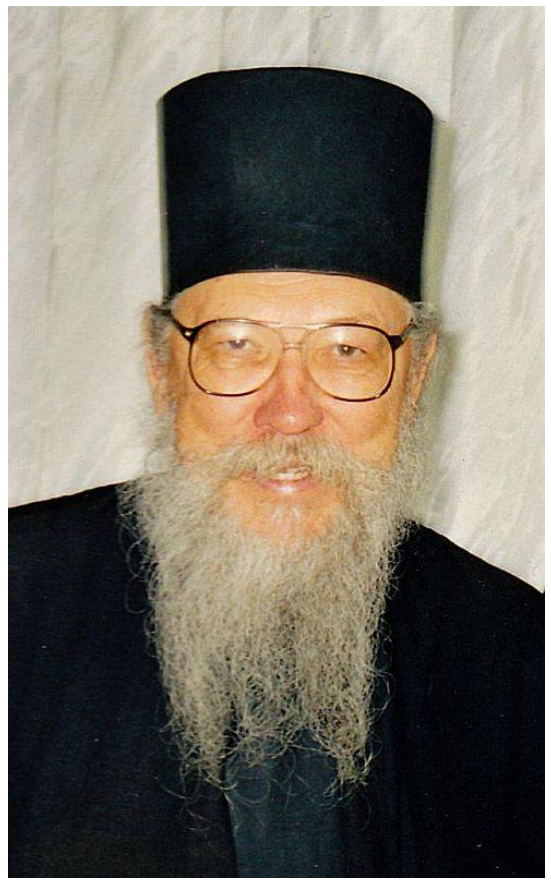

Figure 10. Anon.: Photograph of Abbot Herman (Gleb Podmoshensky), California, ca. 2010.

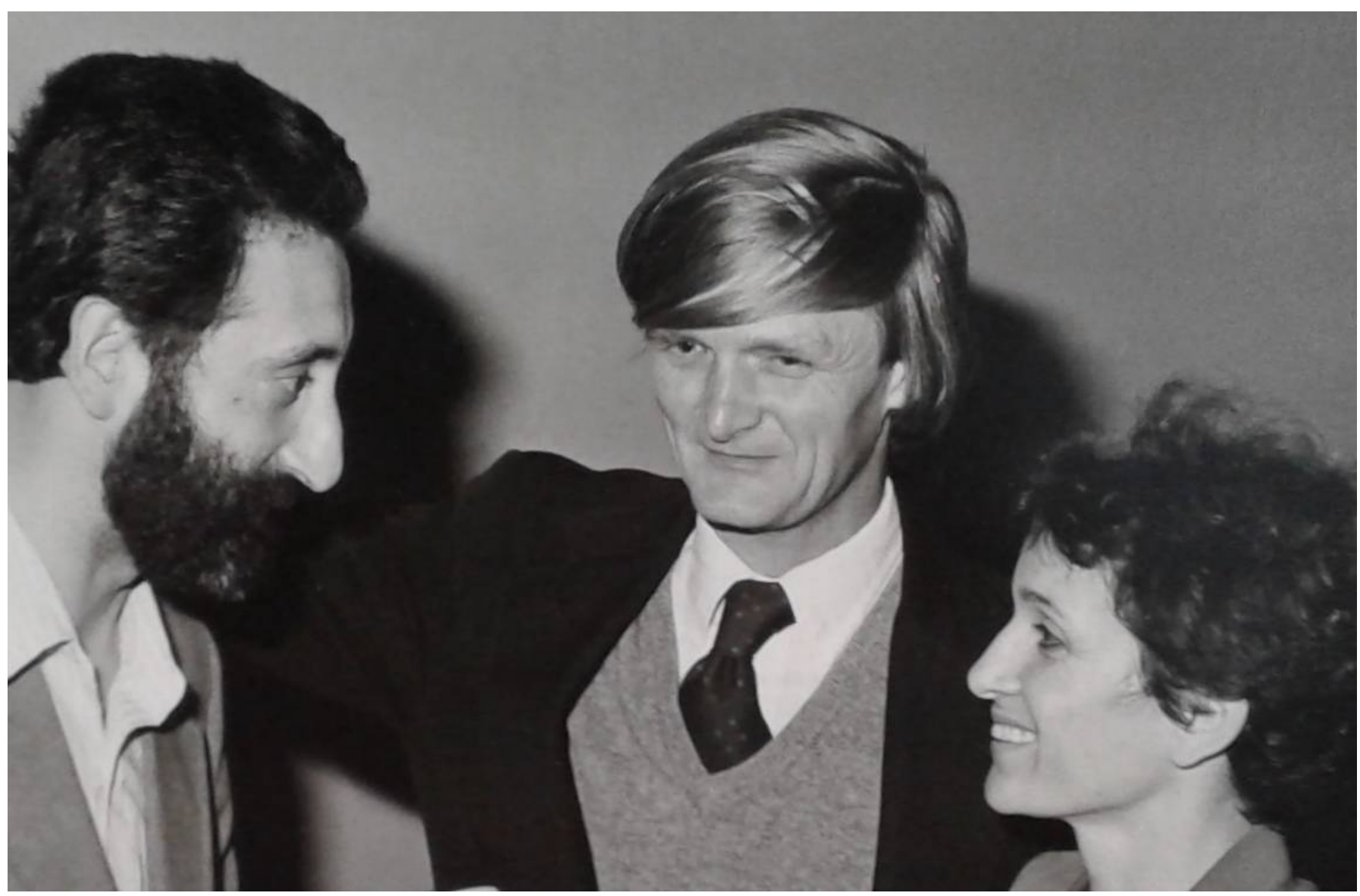

Figure 11. Anon.: Photograph of Lazar Fleishman, John E. Bowlt and Nicoletta Misler at the conference, “Pavel Filonov: Painter of Metamorphosis", held at the Solomon R. Guggenheim Museum, New York, 22-23 April 1983. 


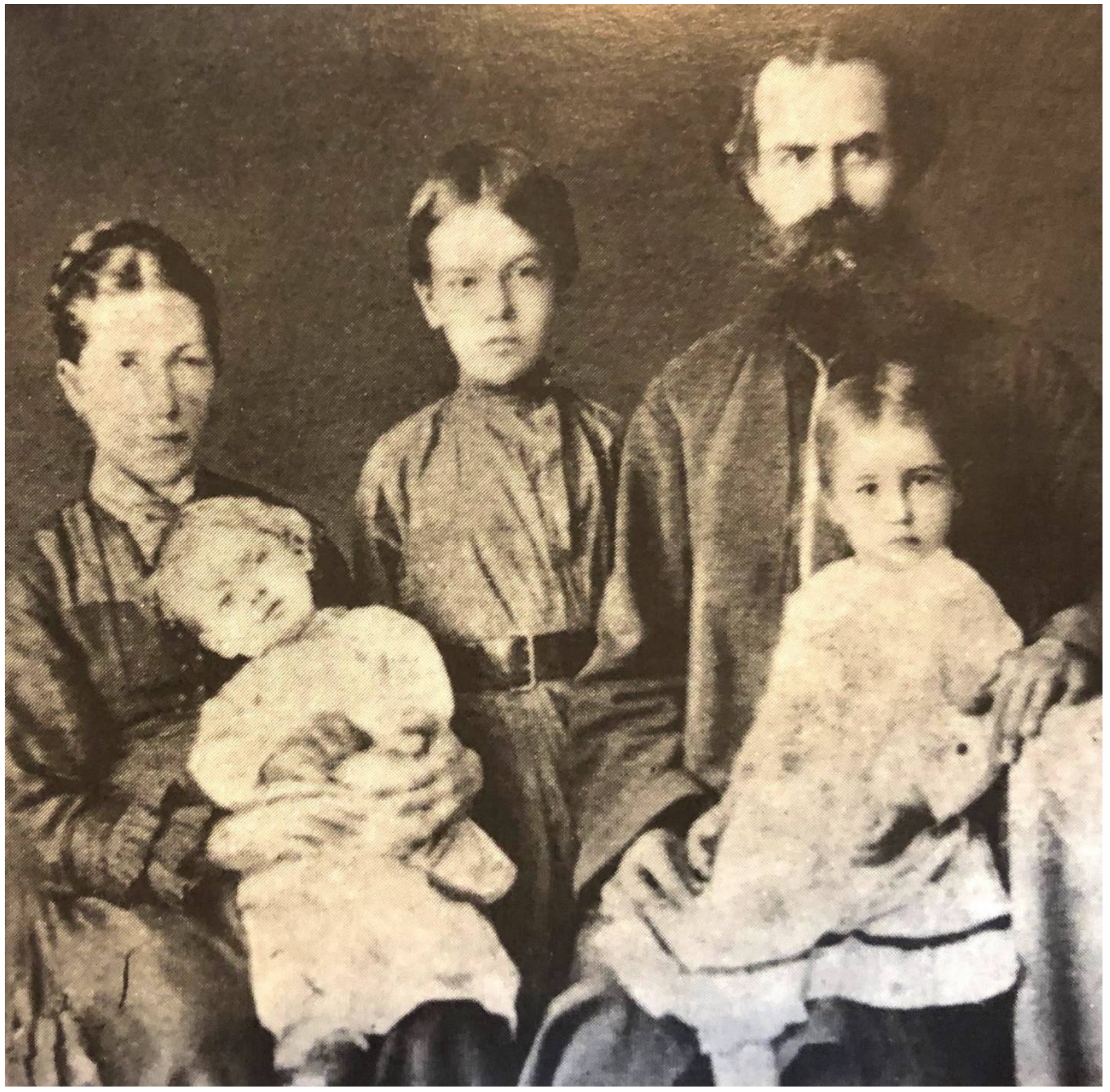

Figure 12. Anon.: Photograph of the Filonov family taken in Riazan' in ca. 1882. From left to right: Liubov' Nikolaevna Filonova, Aleksandra Nikolaevna; Petr Nikolaevich (1869-98); Nikolai Alekseevich (1832-87); Ekaterina Nikolaevna.

After Ekaterina and Aleksandr divorced in 1907 or slightly before, ${ }^{10}$ Ekaterina married a Frenchman (thereby obtaining French citizenship), Arman Frantsevich Aziber (Armand Azibert, 1878-914; Figures 13 and 14), whose family was well ensconced in St. Petersburg society inasmuch as Arman was the owner and director of an important factory of preserves (fruit, vegetables, meat) which, at one time, supplied the Imperial Army. They had two children, Anatolii (sometimes referred to as Nikolia; died in 1913 or 1914 aged four) and René (1910-after 1970?) who also assumed French citizenship thanks to his father, a status which allowed him and his mother to emigrate to France from Leningrad in 1925. Ekaterina and René, figuring on the left side of the Family Portrait, took the icon of St. Catherine, plans and analogous papers related to the Aziber preserve factory in St. Petersburg and, allegedly, a portrait of Ekaterina by Filonov ${ }^{11}$ with them when they emigrated. How Ekaterina and the young René made ends meet in France after 1925 is hard to determine, although the husband and father, Arman, had been domiciled not only at 44, Staro-Petergofskii Prospect in St. Petersburg (the site of his preserves factory which functioned until 1914) where, 
after returning from the front, Filonov also lived for a year, but also (according to his Death Certificate) at 61, rue du Château in Boulogne-Billancourt, an upscale suburb of Paris. ${ }^{12}$ This would mean, presumably, that Ekaterina inherited the French apartment after Arman's death in which case she and René might have relocated there after leaving Leningrad. Subsequently, René married a French woman, Giselle, who survived him, inheriting the icon and the documents of the factory. We saw these items when we visited Mme. Azibert in Hauts de Seine, Sèvres, in 1989.

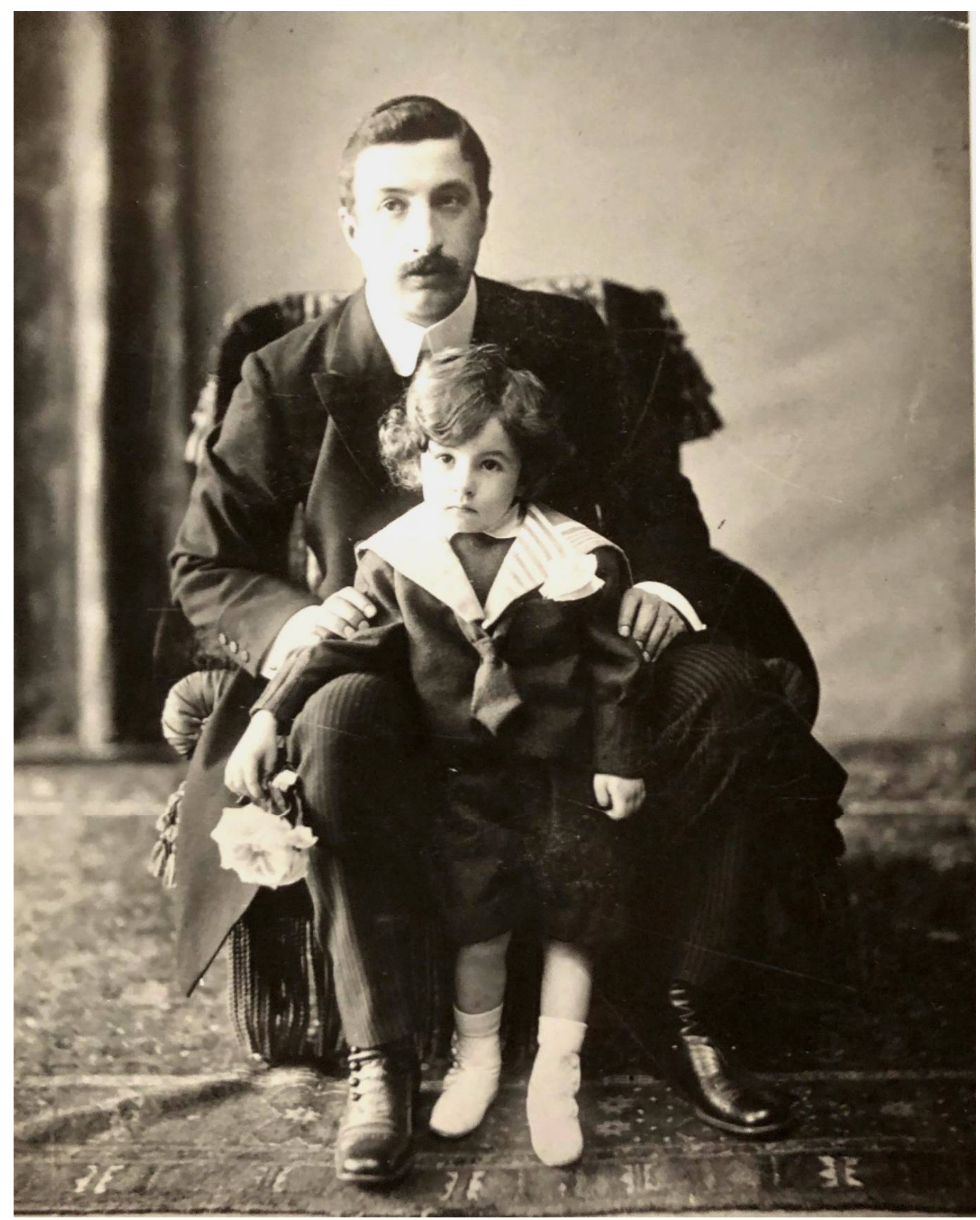

Figure 13. Anon.: Photograph of Arman Frantsevich Aziber (Armand Azibert, 1878-914) and son, Anatolii, 1909-13?), 1913 or 1914 (private collection). 


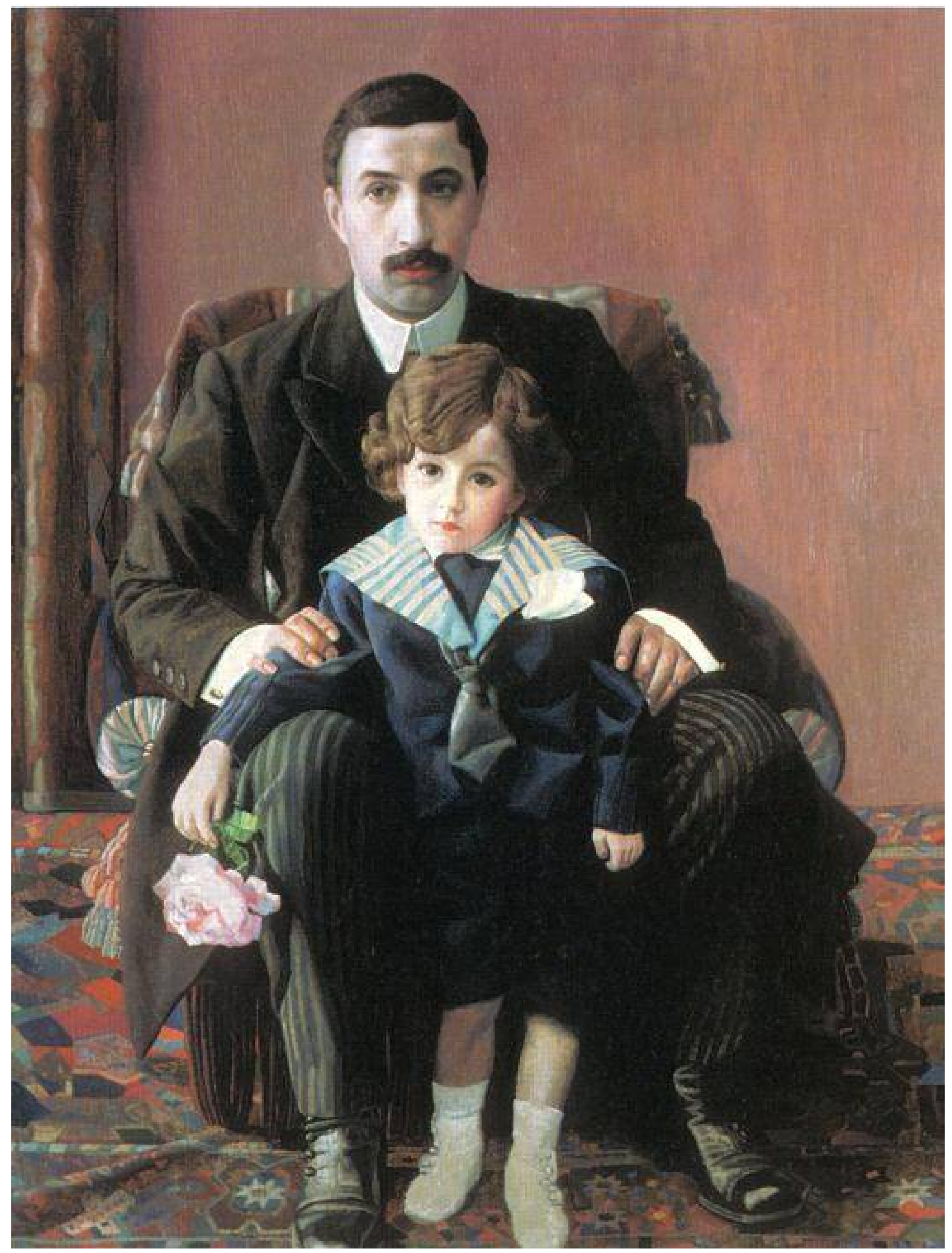

Figure 14. Portrait of Arman Aziber and son, Anatolii (1915; oil on canvas, $115 \times 82$, SRM: Zh 9570). 
Ekaterina's daughter, Nina, remained with her father, Aleksandr, accompanying him and his new wife to Vologda and Tiflis in 1922 and settling in Riga three years later. In 1933 in Riga she married the businessman and paper manufacturer, Dmitrii Ivanovich Podmoshevsky (1904-43), settling with him in Pytalovo (also known as Jauntlatgale and then Abrene) near Pskov and bearing two children, Gleb (1934-2014) and Ia (died 2018), both of whom we met at the Guggenheim Filonov conference. In 1940 the Soviets occupied Latvia and Podmoshevsky was arrested as an "enemy of the people" and deported to prison camp at Vorkuta where he died three years later. In 1942 Nina and her children moved to Germany and six years later joined Alexandra Fedorova in the USA. In the 1960s Gleb became a Serbian Orthodox monk in Boston and then California, assuming the name of Abbot Herman and co-founding the St. Herman of Alaska Brotherhood, the St. Herman of Alaska Monastery (where he served from 1969 until 2000) and the journal Russkii palomnik in Platina, CA, USA (1980 onwards), while his sister Ia moved to London. After her mother's death in 1992, Ia, a devout Orthodox, was also living in California under the surname Schmid (Schmit).

Between 1983 and 1991 we were in correspondence with Nina and in the spring of 1989 took a road trip from Los Angeles to visit her in Napa Valley. Late one morning we arrived at her mobile home just outside the town of Santa Rosa to be greeted by a petite, but vivacious, elderly lady who, immediately, welcomed us in Russian. We spent much of the day listening to her recollections about "Uncle Pania", 13 the Filonov family and also Filonov's Icon of St. Catherine which Abbot Herman had mentioned during our meeting in New York and which Nina remembered well. Although she had not seen the icon since the passing of her mother, Ekaterina, in 1954, she assumed that it was still in Paris, in the home of René Azibert's widow, Giselle, but did not have the street address. Determined to track down the icon, one year later we flew to Paris and, after locating 'Azibert, Giselle' in the Paris telephone directory, called Mme. Azibert, scheduled an appointment and took the train out to her home in Hauts de Seine, Sèvres. A spritely and elegant middle-class lady welcomed us, and, after preliminary conversation, produced the Icon of St. Catherine, wrapped carefully in fabric, from a drawer in the living-room. Naturally, we were overwhelmed by the rediscovery of an artifact which for us had assumed a mythological dimension, although we soon realized that Giselle herself was unswayed by this strange object in bad condition and without a frame, manifesting much greater interest in her father's Sunday paintings of cherries. Incidentally, Giselle also showed us the documents and photographs pertaining to Arman Aziber's factory in St. Petersburg, although, unlike the icon, the fate of those materials remains unknown. In any case, Giselle agreed to loan the icon to the exhibition, 'Pawel Filonow und sine Schule' organized by the Kunsthalle, Dusseldorf, in September-December, 1990, to which we also contributed as essayists for the catalogue. In 2014 the icon was acquired directly from Giselle by a Russian dealer through a French gallery whence it passed into the hands of the Russian collector, Mikhail Suslov.

Ekaterina's and Aleksandr's second child, Nikolai stayed behind in Soviet Russia, was arrested and then freed in 1937, and lived in Pskov and, according to Nina Podmo, during the 1940s (?) she and her mother sent care packages to him. In any case, there is a strong parallel between Abbot Herman and Pavel Nikolaevich, i.e., between the latter's expulsion from the Imperial Academy of Arts (Figure 15) and then the reinstatement in 1910, and Herman's own iconoclastic activity, because, for all his dedication to the Orthodox cause, in 1988 the Synod of Orthodox Bishops excommunicated him for alleged impropriety, a scandal which drove him into spiritual exile and isolation. 


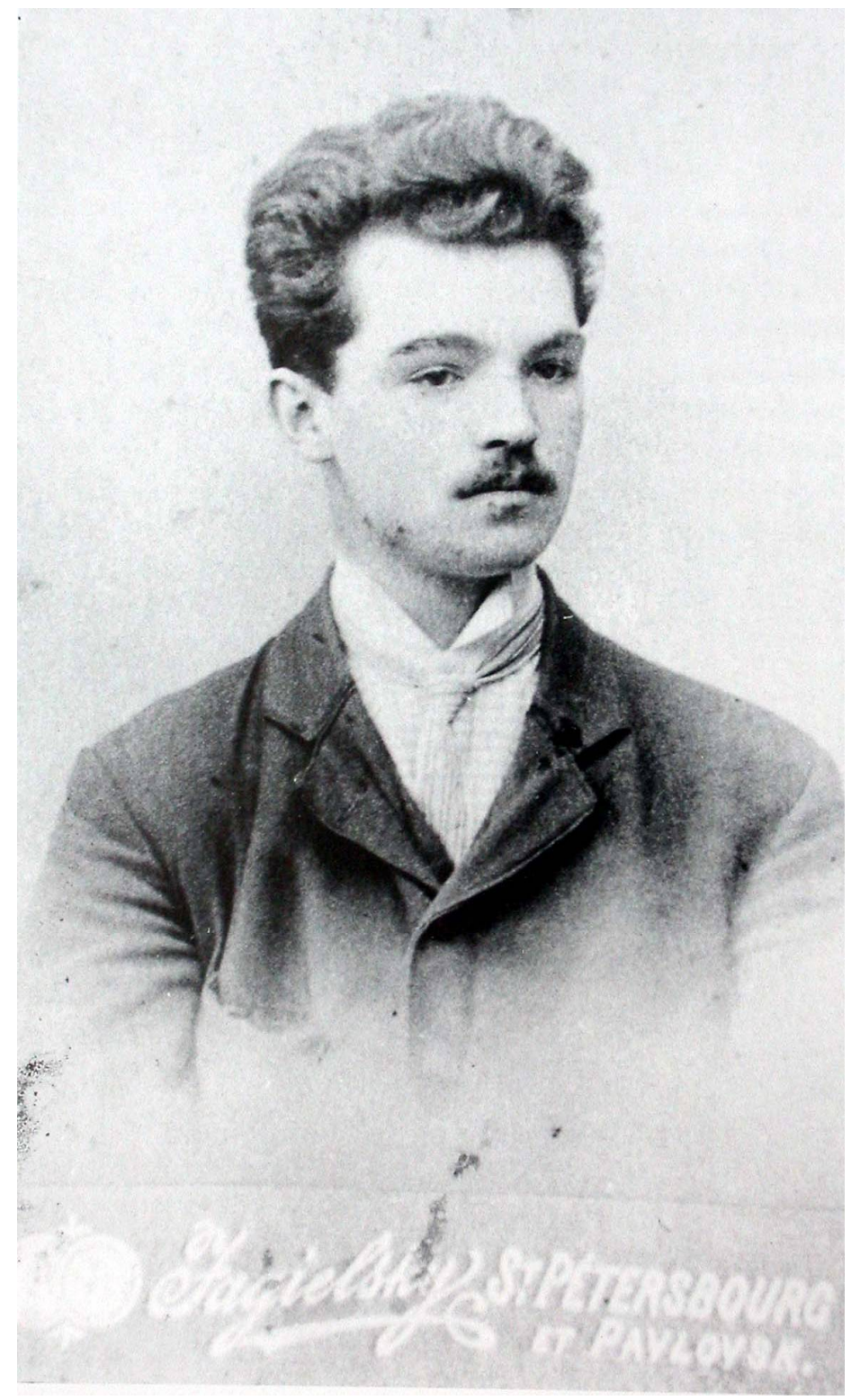

Figure 15. Aleksandr Yagel'sky, photographer: Pavel Filonov as a freshman at the Imperial Academy of Arts, St. Petersburg, 1908.

As for Arman Aziber (Armand Azibert), fresh information has come forth recently regarding his life and work, which helps clarify his position in the St. Petersburg business world and certain issues surrounding the extraordinary oil Portrait of Arman Aziber and His Son which Filonov painted in 1915. The assumption that Filonov had painted this double portrait from a photograph after Arman had died in action at Souain Perthes-lès-Hurlus, Marne, on 29 February, 1915 (according to his Death Certificate) was often questioned and, in fact, at least one source still denies the rumour, asserting that the portrait was painted from life ${ }^{14}$ - even though Filonov himself mentioned that the portrait was "after a photograph"15 and the actual photograph was discovered among family papers and reproduced for the first time in the Dusseldorf catalogue of the Filonov retrospective, ${ }^{16}$ providing ample testimony not only to Filonov's phenomenal skill— to his 'Photo-Realism' but also to his delicate pictorial adjustments and impositions as in the facial expressions, the hairstyles and the carpet. The carpet, in fact, recalls the luxurious fabrics of Mikhail Vrubel's Girl against a Persian Carpet (1886, Figure 16) where the model holds a pink rose much as the boy does in the Aziber portrait, and of Fortune-Teller (1894-96; State Tretiakov 
Gallery, Moscow). Here, is the same kind of minute elaboration and organic decoration as in the florid mantle of Filonov's Icon of St. Catherine or her ornamental scroll, the script of which is still entirely legible, i.e., Verse 7 from Psalm 139: "Kuda poidu ot Dukha Tvoego, $\mathrm{i}$ ot litsa Tvoego kuda ubegu" [Whither can I go to escape Your Spirit? Whither can I flee from Your presence?].

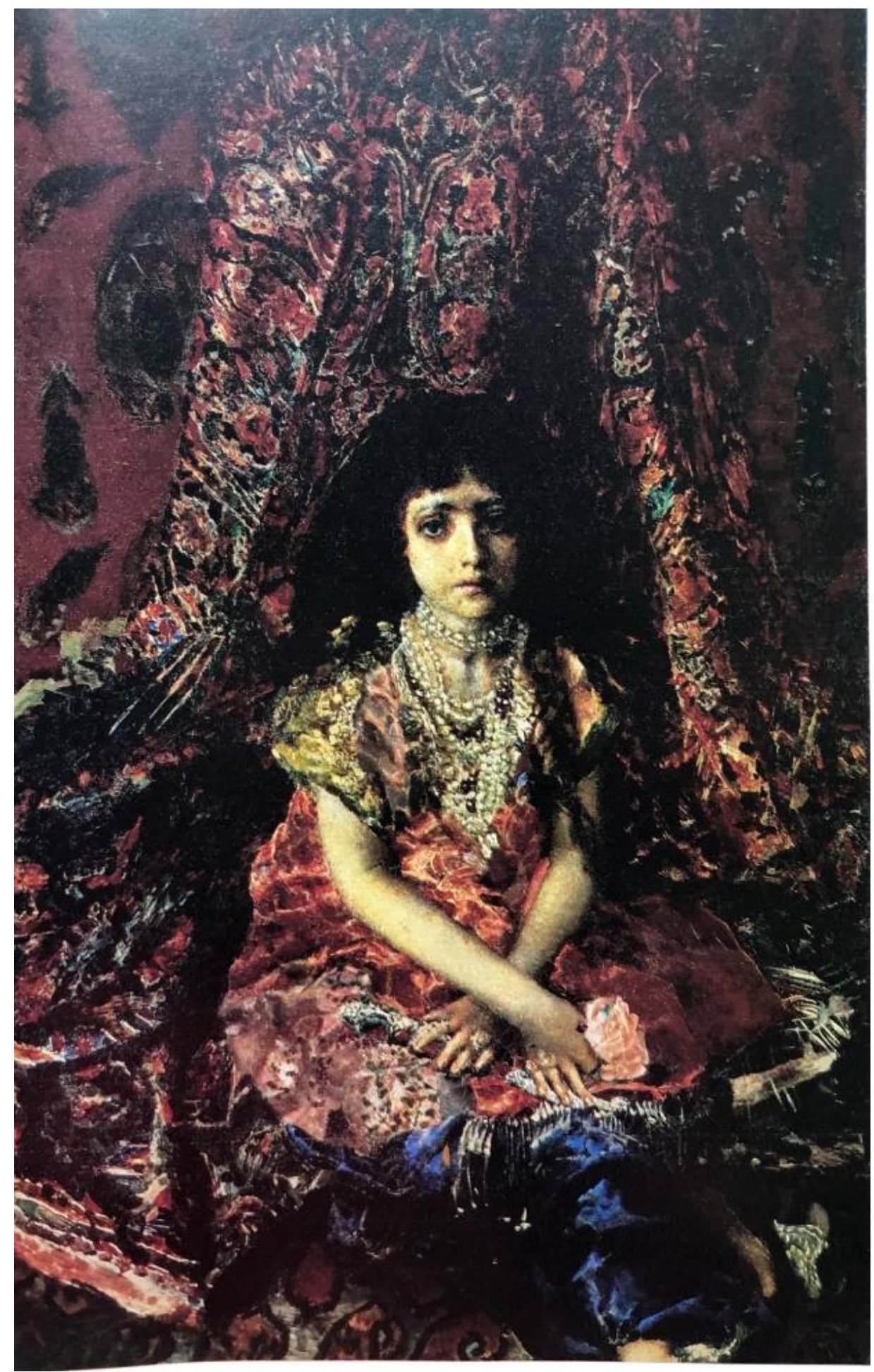

Figure 16. Mikhail Vrubel: Girl against a Persian Carpet (1886, oil on canvas, $104 \times 68$, Museum of Russian Art, Kiev). 
It is almost as if Filonov, expelled from the Academy of Arts in April, 1910, for his "disgusting drawings and studies", but convinced that "I can also work with any technique, coming right down to the natural world" 17 was reminding the establishment that, however "incorrect" and unorthodox his own Analytical art, if need be, he could also execute perfectly academic and "correct" paintings. Indeed, however we judge the Portrait of Arman Aziber and His Son, it is a haunting, if not, ominous, memento mori, challenging us to accept the sudden death of a flourishing businessman, of a first born, Anatolii (presuming that the boy is, indeed, Anatolii), even of a freshly cut rose. In any case, the photograph must date from before August, 1914, when Arman volunteered for the front and joined the 130th Régiment d'infanterie. That the son here is Anatolii rather than René can be deduced from comparison of the photograph of the young René taken in ca. 1920 (on the left of Figure 17) as well as the photograph of him published on the internet dated 1923 and his portrait in Family Portrait, all of which differ markedly from the child in Portrait of Aziber and His Son. This conclusion, therefore, contradicts the general assumption that this is René rather than Anatolii. ${ }^{18}$

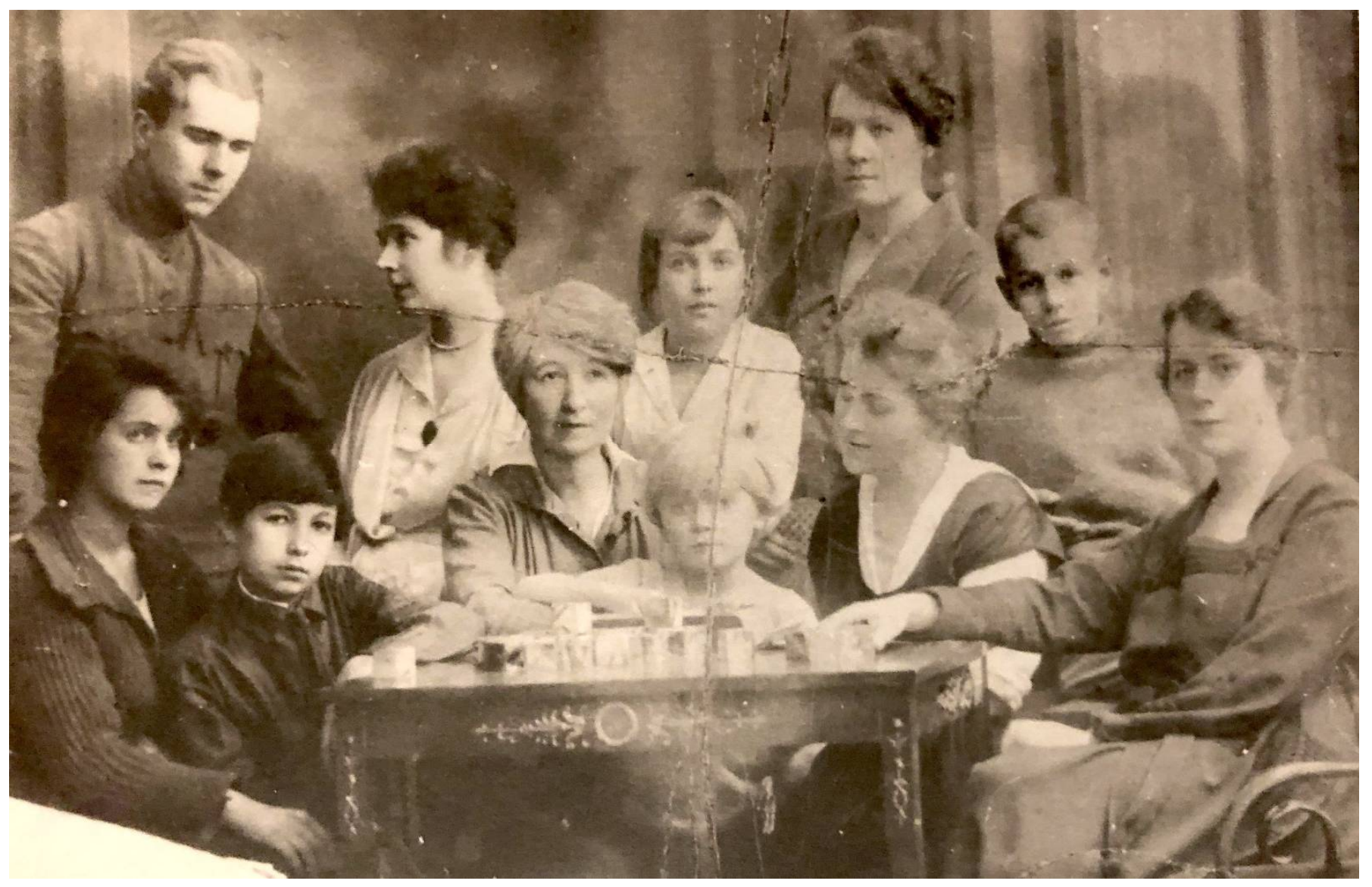

Figure 17. Anon.: Photograph of members of the Filonov family, Petrograd, ca. 1920. Left to right: Nikolai Aleksandrovich Gue; Liubov' Aleksandrovna Gue; René Aziber (Azibert); Aleksandra Aleksandrovna Gue; Ekaterina Fokina-Aziber; Mariia Aleksandrovna Gue; Vladimir Aleksandrovich Gue; Aleksandra Niklaevna Filonova-Gue (seated); Mariia Nikolaevna Filonova (seated); Nikolai Aleksandrovich Gue; and Evdokiia Nikolaevna Filonova (Glebova-Putilevskaia).

\section{Keeping the Faith}

The Orthodox connection, in particular, betrays Filonov's upbringing in a strict, Christian family (Podmo recalled that "Filonov belonged to the merchant class, so his parents had brought him up in the Orthodox faith"), ${ }^{19}$ with its unfailing celebration of Easter, something which latently, at least, remained a vital point of departure for his aesthetic and philosophical journey, even transmuting itself in some of the politically tendentious 
and atheist pictures of the Soviet period. In any case, according to his autobiography, Filonov undertook a pilgrimage to the Holy Land in 1907, visiting Constantinople, Mount Athos, and Jerusalem, and the Monastery of St. Catherine in the Sinai Desert, ${ }^{20}$ painting souvenir icons en route to cover his expenses-a prelude to master paintings such as St. George, the Victorious, Mother and Holy Family. ${ }^{21}$ Additionally, according to his autobiography, Filonov copied an engraving of a Crucifixion for monks in Jerusalem, which perhaps looked forward to his Golgotha (1912, Figure 18) and two other paintings of the crucifixion, i.e., Execution (After 1905) 1913, (Figure 19) and Execution (1920-21, Figure 20). In 1914 Filonov even argued that the artistic center of gravity was moving to Russia, "our motherland, creator of marvelous temples, of the art of artisans and of icons". ${ }^{22}$

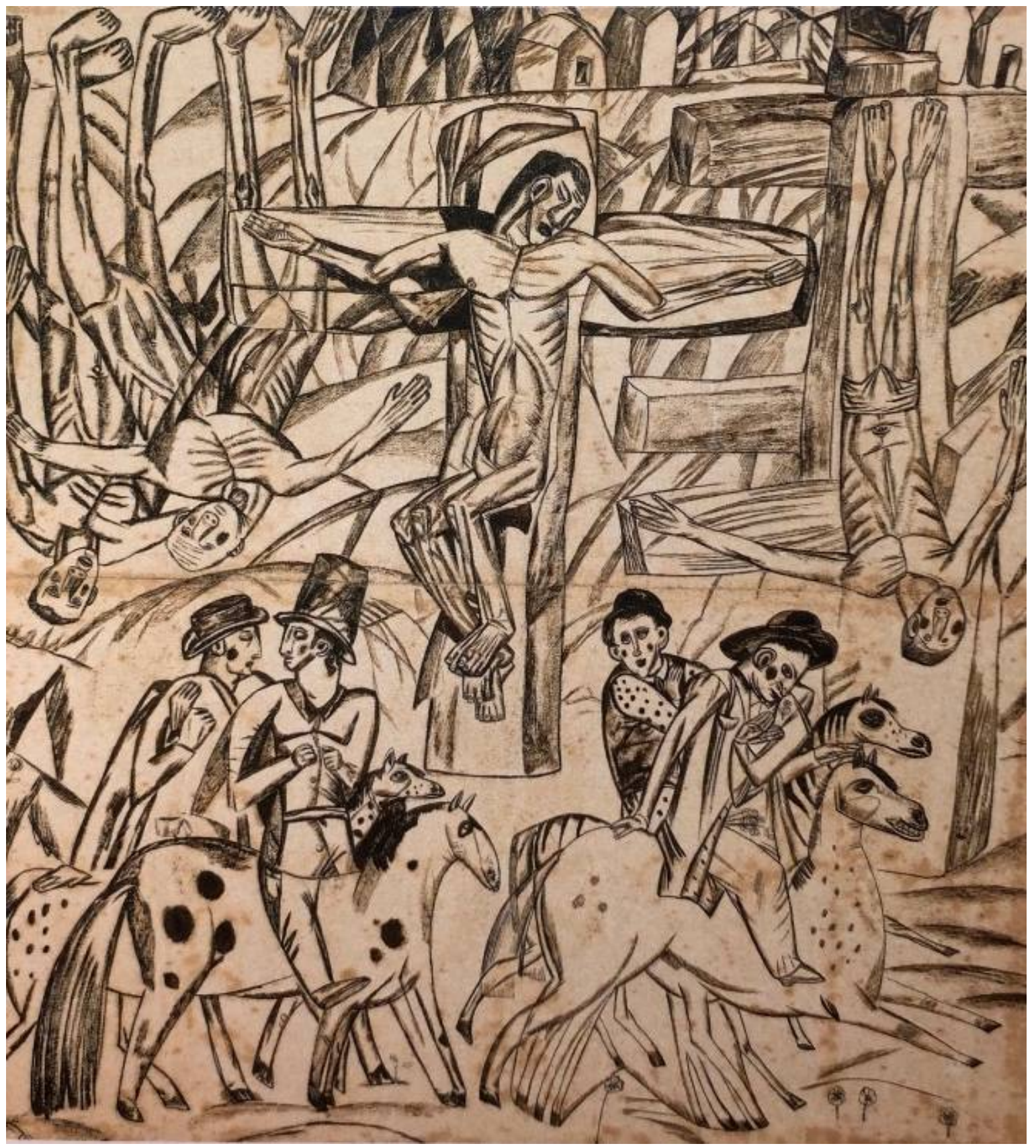

Figure 18. Golgotha (1912, pencil and watercolour on paper, $33.5 \times 32.7$, State Tretiakov Gallery, Moscow: R 2918). 


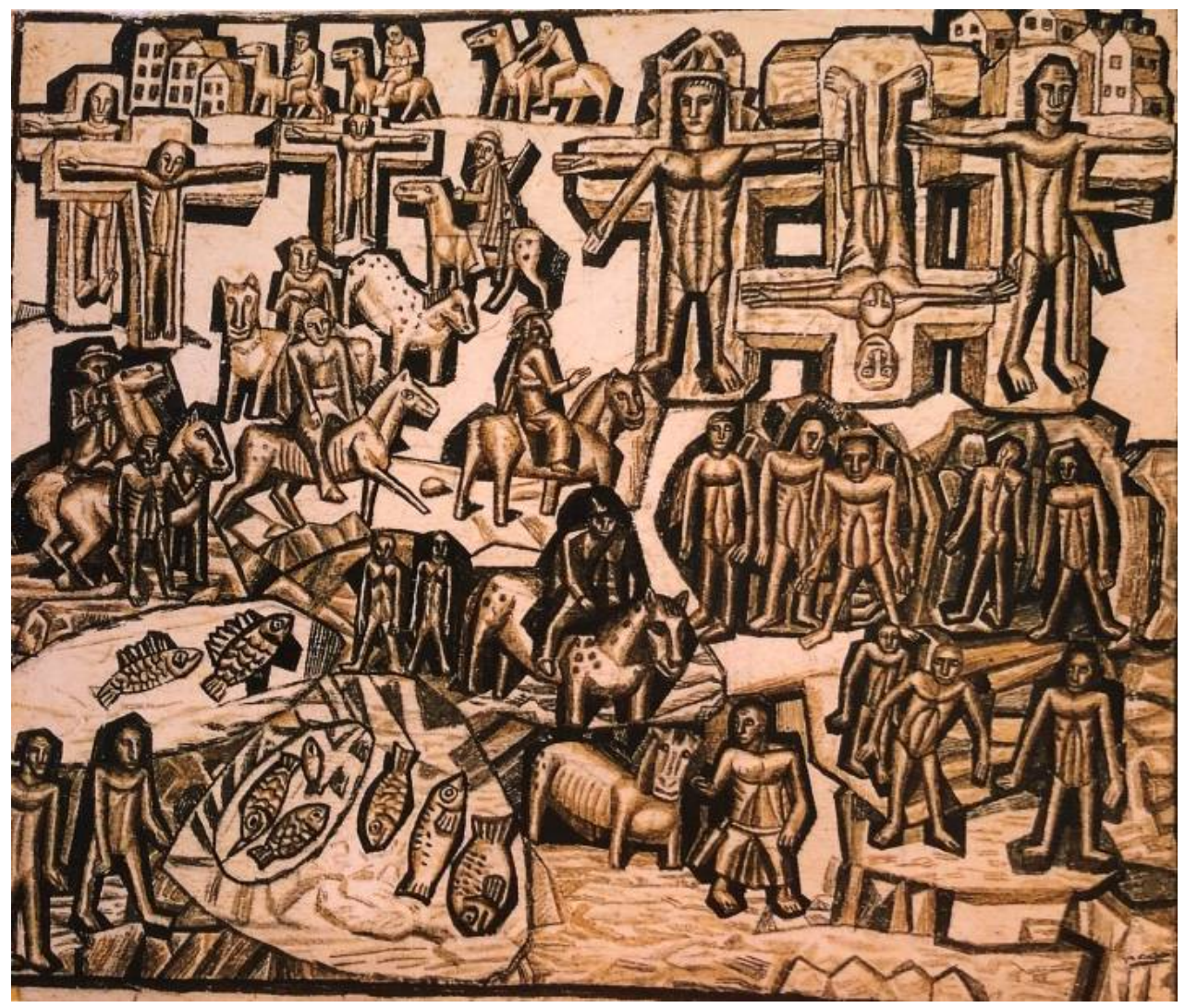

Figure 19. Execution (After 1905) (1913, brown ink and pencil on paper, $11.6 \times 13.4$, SRM: R 58236).

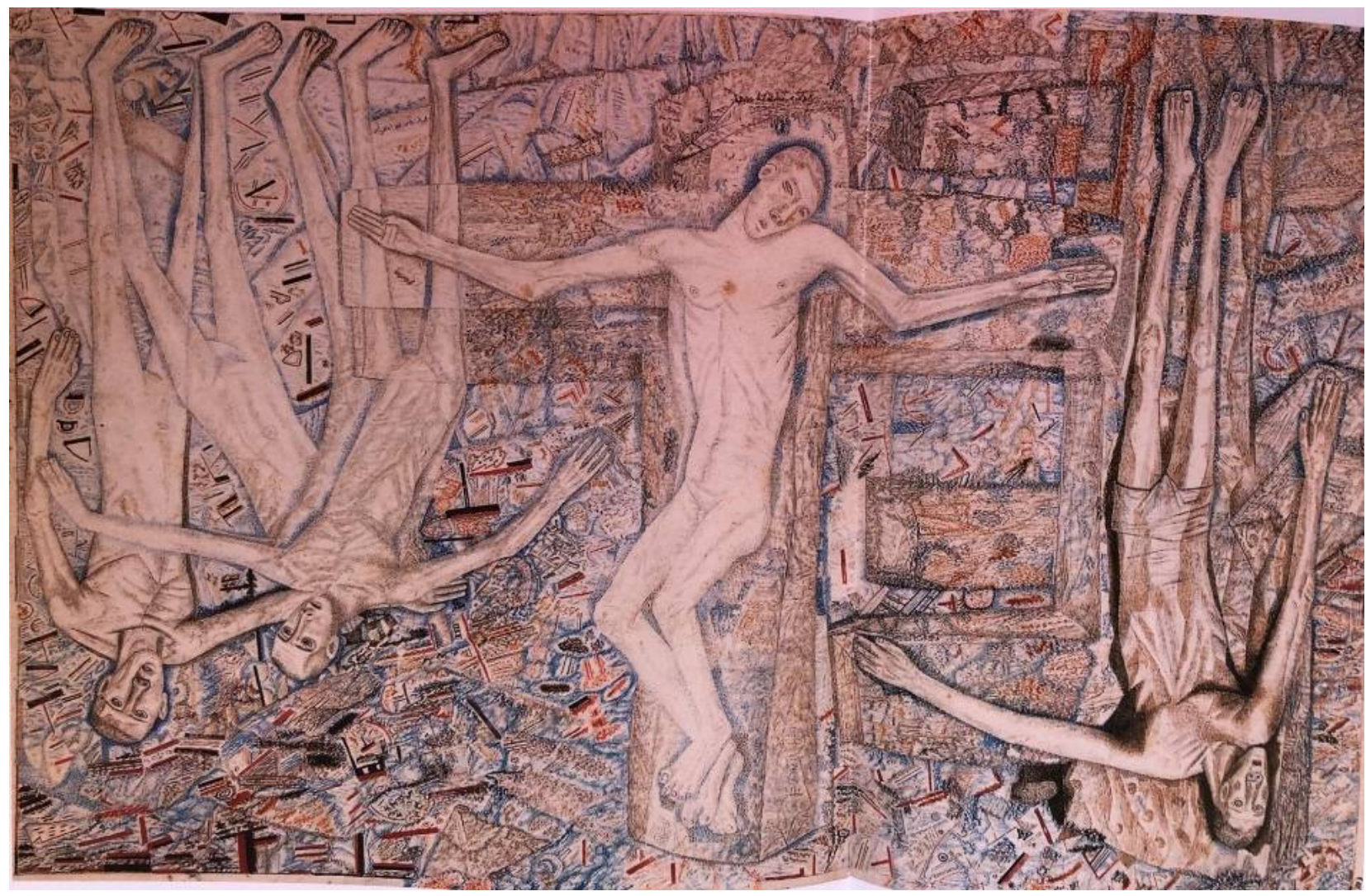

Figure 20. Execution (1920-21, watercolour and mixed media on paper, $27.8 \times 44.5$, SRM: R 14867). 
Some of Filonov's paintings of the Soviet period with their manifest crosses and Madonnas, still carry remnants of the Christian symbology for all their Communist veneer and, after all, Filonov did hang a few Biblical scenes in his one-man exhibition at the State Russian Museum in 1930 (which did not open). For example, there was Abraham and the Holy Trinity (1912; Figure 21), Easter (1912-13) and Adoration of the Magi (1913). Furthermore, in the 1920s and 1930s Filonov continued to refer to icons in his public statements and lectures, praising icon-painters, for example, in his essay on the "Proletarianization of Visual Art" 23 and rejecting the Byzantine influence on Russian icons in his 'Declaration of "World Flowering". ${ }^{24}$ In the programme for the reform of the Petrograd Museum of Painterly Culture which he outlined at the Conference for the Reorganization of Museums in 1923 Filonov included various 'peripheral' disciplines, including the art of children, of the insane, of self-taught artists and also icons- 'in covers and without, new and old styles, moving on from the Byzantine and Russian cathedralic canon of Athos and Jerusalem'. ${ }^{25}$ Given Filonov's support of the Communist Party's militant atheism, during the Soviet period his religious motifs sometimes become anti-religious ones, even cartoons as in Last Supper (1920s-early 1930s, State Russian Museum, St. Petersburg). At the same time Filonov reinforced his new ideological stance by issuing emphatic statements condemning religion both as a hierarchical institution and as a source of artistic inspiration: 'The matter of Russian and global art is, in all its theoretical and ideological interrelationships, the same as in questions of religion, the church, believers and God with all His rituals. And together with all their gods and saints, with their mysteries of creation, with all their prophets, priests, harbingers and wizards of art, all these interrelationships must also be destroyed' ${ }^{26}$

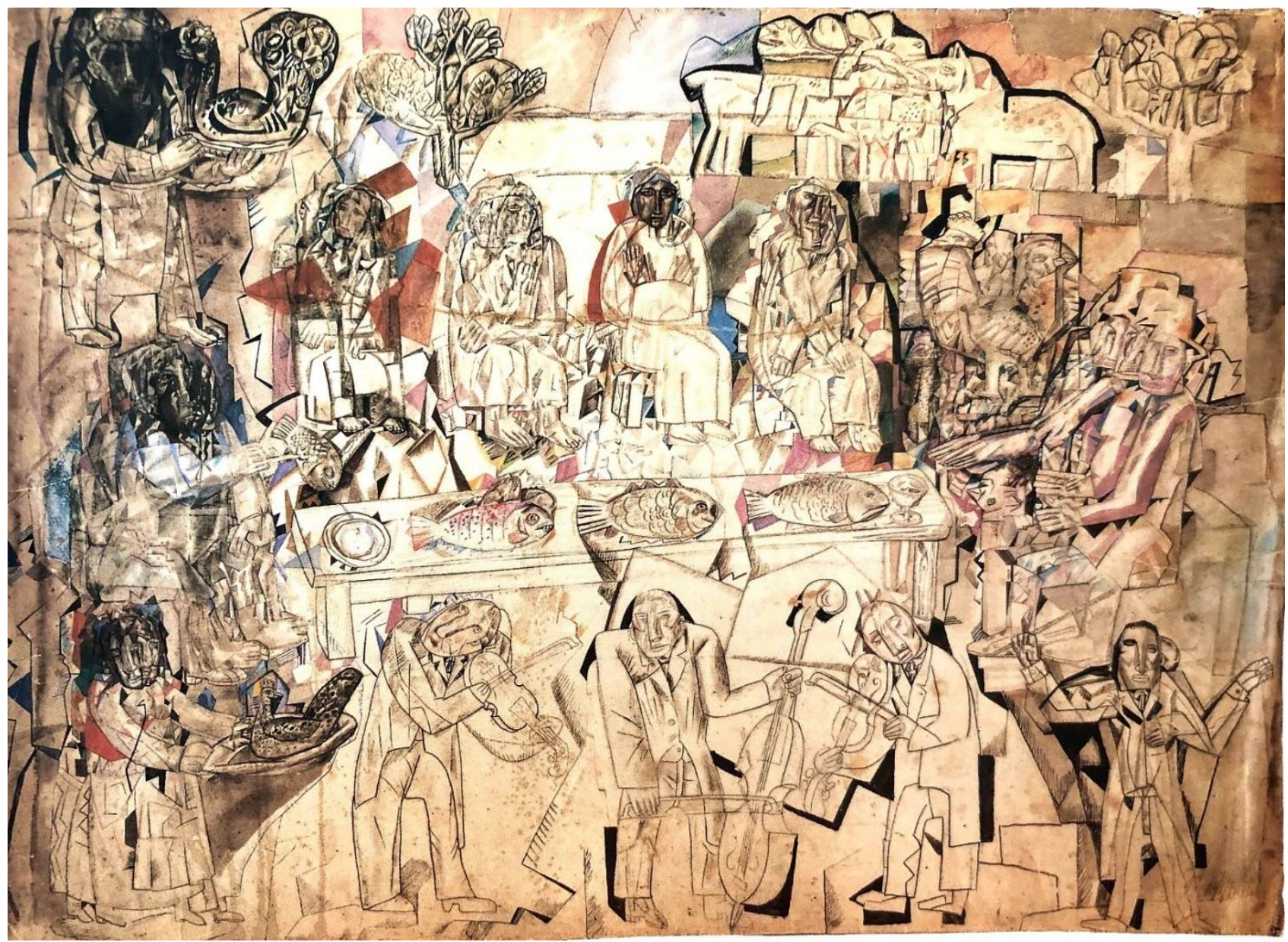

Figure 21. Abraham and the Holy Trinity (1912; watercolour, Indian ink and pencil on paper, $70.9 \times 95.5$, SRM). 


\section{The Icon of St. Catherine}

Although, before 1917, Filonov painted a number of major paintings on Evangelical themes, he was not, primarily, a religious painter and, after all, his sister, Ekaterina, may well have suggested the topic of an icon to him and even to have dictated certain prerequisites. Perhaps the fact that the Domestic Church at the Imperial Academy of Arts, Filonov's alma mater, was dedicated to St. Catherine, the Martyr, may also have influenced the choice. The extent to which Filonov was following his own theory in the icon vis-à-vis what appears to be its original prototype-a 17th century icon from the Stroganov school in the Cathedral of the Intercession in Rogozhskaia sloboda in Moscow-tells us how faithfully he was keeping to the antique formulae on the one hand, but how innovative he was, on the other. ${ }^{27}$

If we compare Filonov's Icon of St. Catherine and the original upon which, apparently, it was based, we can see how closely he followed the iconographic canon, while also diverging. With her royal crown and precious mantle, Catherine stands upright and majestic like a princess, one hand with the two-finger, Old Believer gesture of blessing, the other holding the scroll. The exotic architecture duplicates what we see in the Moscow icon, although perhaps the exclusion of other narrative elements is justified by the fact that Ekaterina, Filonov's sister, may have dictated her own preferences (or they may be missing simply as a result of wear and tear). As for the omission of the martyr's wheel and the palm (signifying Christian victory), Orthodox elders explain that the "wheel [and palm] is a Catholic influence which is why you find it in only the crusader icons at Sinai and in icons which have been copied from them, i.e., this is a 'foreign' influence, which the Old Believers would have avoided." ${ }^{28}$ In any case, however canonical the icon may be, the flower at Catherine's feet, even if repeating the accepted model, now merges into a strange animal-vegetable form, just as the intense ornament of the mantle seems to be undergoing an organic metamorphosis. Incidentally, once again, this kind of biological 'degeneration' reminds us of the ornamental promiscuity visible in the late works of Vrubel' - who, a fellow "Decadent", exerted a formative influence on Filonov. ${ }^{29}$ With his demonic subjects, crepuscular tones and fragmented surfaces, Vrubel' evoked a nether world of anxiety and despair, a mood identifiable with much of the culture of fin de siècle, and although, in his writings, Filonov does not mention Vrubel', he would seem to be sharing the notion that traditional values - of the Academy and of Realism, in particular-had fallen from grace and were to be replaced by new criteria. Indeed, one of the most striking elements in Icon of St. Catherine is the mantle with its intense decoration painted in accordance with Filonov's Analytical system, encompassing the "genesis of being, the pulsation of the sphere." ${ }^{\prime 30}$ His was a sensibility which heeded the living processes of nature right down to the "physiological processes in trees ... their smell ... creating phenomena" ${ }^{31}$ —which is to say that Filonov perceived form, including artistic form, as a living unit, like a plant or animal.

Of particular interest is the technical structure of the Icon of St. Catherine which, in some respects, contravenes the methods of traditional icon-painters, a fact illuminated by the inspections of museum professionals, first at the State Russian Museum, St. Petersburg, in January, 2014, and then at the State Tretiakov Gallery, Moscow, during 2019, the second report being more thorough than the first. The State Russian Museum concluded that the medium of the icon was "mixed" (including temper) and that Filonov's "careful processing of the board, the pavoloka [fabric] made up of three different sized segments and the levkas are testimony to a conscious application of the devices of icon-painting". ${ }^{32}$ On the other hand, the findings of the specialists at the State Tretiakov Gallery, above all, senior restorer, Yulian Khalturin, more comprehensive and more precise, point to the opposite, i.e., that "Filonov was foreign to the technique of the professional icon-painter, witness to which were his application of materials and his methods of execution, for example, how the canvas and its ground (the ground being more typical of oil painting) had been combined with the very thin stratum of the depiction itself, something creating a far from durable structure. Canvas is a material which ... is subject to contraction and expansion (especially 
if it had never been attached to the board). In that case, the thin layer of paint will react... and detach from the ground completely". 33

In effect, Filonov much preferred oil painting, often applying it with a thin brush even to paper (an application far from secure) so we should not be surprised to see it in his icon, an element separating the artifact from the Orthodox iconic tradition. Furthermore, as Khalturin comments, "Traditional icon-painting technique ensures a stable connection with the wood", whereas Filonov favored a more experimental method, something which, once again, emphasizes the distance between Filonov the studio painter and Filonov the icon painter. The Icon of St. Catherine, with its organic embellishments, also brings us to the question of time in the sense that, for the icon-painter, what counts is the actual time spent on preparing the sacred icon, i.e., on creating the various strata and sediments which make for the fast attachment of the image to the board. For Filonov, time meant 'time of execution', something quite different, because the production of the surface image, as opposed to the physical support, had to be slow and measured so that 'Every atom be made ... Think obdurately and accurately over each atom of the work being made'. ${ }^{34}$ Such an approach led Filonov to apply a "thin, but bright and variegated, sometimes semitransparent paint which presumably, was very effective, but not durable. The very presence of a grid tells us that [Filonov] was, probably, copying a specimen ... The original painting is distinguished by a richness of colour, looking almost like watercolour (especially) visible in the architecture and on Catherine's sleeve and shoes."

Khalturin also observes that "We should also remember that there is a thick layer of drying-oil (olifa)in this icon and that this can tear the paint away from the surface. We can see that, initially, the artist had made a pencil grid, which helped him reproduce the subject-matter. Using a microscope allows one to see the difference more clearly, since to the untrained eye the impression is erased owing to the dirty varnish which has been removed unevenly and destroyed". 35

That in his icon Filonov had used a varnish detrimental to the image reminds us that in some of his easel paintings he would apply a varnish which tended to drip down and darken the surface, as, for example, in Man and Woman (1912-13, State Russian Museum, St. Petersburg) - which is to say that the issue of Filonov's technical devices, especially during the 1910s and 1920s, is of paramount importance to our understanding of his artistic versatility - as, for example, his use of oil on paper, a difficult and disjointed technique which, thanks to the distinctive, jewel-like quality of his execution, permitted him to attain a pictorial surface of particular brilliance-easily recognizable in the fine detail of St. Catherine's mantle.

Wear and tear have damaged, even cancelled, entire sections in the Filonov icon, including parts of the buildings on the right and left of the Saint, the faithful at her feet and perhaps a scene of her entombment top right. It is also possible that at one point the secondary figure of Catherine, visible lower right, for example, in the Moscow version and other specimens, was also present here, which might also mean that at some point part of the righthand side of the icon was cut. In addition, the vestiges in the lower far left allude to the kind of host of heads and faces with which Filonov populated other pictures of the same period such as Heads (1910, State Russian Museum, St. Petersburg, Russia) and he may also have repeated the cameo of Christ in His cruciform halo surrounded by angels, lowering a censer towards Catherine's right palm visible in the Moscow version. The cameo to the right, on the other hand, is an unusual supplement, but may represent a heavenly Jerusalem or Paradise which is often painted with white background and green trees or bushes next to the building, the moreso since the vault behind the circle is dark blue with a personified sun. In any case, for all the missing links and material blemishes, Filonov's icon remains a very close copy of the Moscow original, although the circumstances under which he travelled to the Cathedral (if he did so) and painted his version and how his sister responded are open to conjecture. True, Filonov could have seen black and white reproductions of the Moscow icon in published sources, especially in Nikolai Likhachev's magnum opus on the history of icon-painting. ${ }^{36}$ 


\section{Coda}

Examination of Filonov's Icon of St. Catherine demonstrates that Orthodox does not automatically signify orthodox and that an artist such as Filonov, radical and uncompromising, could find inspiration in one of the most ancient and hieratic traditions of Russian culture-the icon. The confrontation also indicates that, however prodigal and intransigent in behaviour, Filonov was still bound by the canons and conventions of his upbringing-by family, Christianity and the Romantic notion of the artist as witness to the unseen. Even if Filonov interpreted the Biblical story in a very private manner and in later life even replaced it with a Soviet hagiography, he remained faithful to his vision of art as a vehicle of spiritual remedy and transformation. After all, painting is believing.

Author Contributions: All authors contributed equally to this work. All authors have read and agreed to the published version of the manuscript.

Funding: This research received no external funding.

Institutional Review Board Statement: Not applicable.

Informed Consent Statement: Not applicable.

Conflicts of Interest: The authors declare no conflict of interest.

\section{Notes}

1 For more information on Filonov see (Misler and Bowlt 1983; Kovtun 1988; Petrowa and Harten 1990; Gmurzynska et al. 1992; Misler et al. 2005; Bowlt et al. 2006; Petrova 2006, 2008; Pravoverova 2008; Sokolov 2008; Ershov 2015; Pravoverova 2020).

2 After 1917 Filonov changed the title Holy Family to Peasant Family, even though, according to Irina Pronina, the picture may not only depict the Holy Family, but also carry a reference to the Massacre of the Innocents and to the Russian pogroms (Pronina 2010). A second so-called Peasant Family dated 1912-14 (watercolour; $36 \times 46$ ), which would seem to be another interpretation of the Holy Family, is reproduced in (Kriż 1966), plate 6.

3 P. Filonov: "Avtobiograficheskie teksty" in Bowlt, Misler, Pronina, Sarab'ianov, p. 78. English translation in (Misler and Bowlt 1983, p. 122).

4 P. Filonov: "Try with all your might to study nature and transmit it exactly [toch' $\mathrm{v}$ toch']" - 'Pis'mo nachinaiushchemy khudozhniky Baskanchinu" (19 February 1940) in Bowlt, Misler, Pronina, Sarab'ianov, p. 198. English translation in (Misler and Bowlt 1983, p. 291).

5 This religious or, rather, Christian, aspect of Filonov's oeuvre has received relatively little attention, although mention should be made of the following: N. Misler; "Von der Ikonenmalerei zum Fotorealismus" in (Petrowa and Harten 1990), pp. 36-49; Pronina, "Shkola Filonova: neizvestnye stranitsy istorii"; and Elena Fadeeva's dissertation, i.e., "The Judgement Day of Art". Orthodox Iconography, Messianism and Martyrdom in the Art of Pavel Filonov", for Master of Literature at the School of Art History, University of St. Andrews, Scotland, in 2014-15.

6 Among the many individuals who rendered valuable assistance during our researches for this essay we would like to mention the following: Konstantin Akinsha, Robert Chandler, Donna Decker, Isabelle Fokine, Il'dar Galeev, Lynn Garafola, Musya Glants, Ol'ga Golubeva, Viktor Golubinov, Yulian Khalturin, Viktor Men'shikov, Irina Men'shova, Ol'ga Pal'chevskaia, Wendy Perron, Evgeniia Petrova, Jane Pritchard, Irina Pronina, Ksenia Radchenko, Elena Rybakina, Oksana Rybakina, Ol'ga Selivanova, Sister Gabriela, Wendy Salmond, Yuliia Solonovich, Mikhail Suslov, Mariia Trubacheva, Boris Yavdin, Andrei Vasil'ev, Zel'fira Tregulova and Arlene Yu. The following depositories were also consulted: Military and Historical Society, Moscow; Russian State Archive of Literature and Art, Moscow; Russian State Archive of the Military and Maritime Fleet, St. Petersburg; State Military and Historical Archive, Moscow; State Russian Museum, St. Petersburg; State Tretiakov Gallery, Moscow.

7 In the catalogue of Filonov's one-man exhibition at the State Russian Museum in 1930, the work is entitled Family Portrait without the word 'Easter'. See (Isakov 1930), Introduction, No. 162.

8 On the Filonov family hailing from Riazan' see Semina (2017), pp. 6-13.

9 In 1917 director and actor Konstantin Mardzhanov took over management of the Troitskii Theater, but it closed down five years later.

10 Judging from an affectionate dedication to Ekaterina and Arman, dated 16 April 1907, in a book given to them by the lawyer, Grigorii Osipovich Rozentsveig, i.e., Iz zaly suda. Sudebnye ocherki i kartinki (St. Petersburg: Trud, 1900), the couple were already engaged, if not, married. The book was offered at auction by the Moscow auction house, Antikvarium, on 3 December 2015.

11 See (Glebova 1984): 'Dnevniki Filonova v vospominaniiakh', p. 150. Evdokiia Glebova (Filonova, 1888-1980), married to Nikolai Glebov-Putilovsky, was Filonov's youngest sister. In her monograph of 2008 (Pavel Filonov, Real'nost' i mif, p. 237) Pravoverova wrote that the portrait was in the possession of René Azibert in Paris. 
See http:/ / www.culture.fr/ (accessed on 3 June 2021) at: http:/ / shorturl.at/uwFOY (accessed on 3 June 2021).

See N. Podmo: 'Uncle Pania' in Gmurzynska, pp. 173-76.

See (Stolbova 2012), p. 11. According to Stolbova, Ves' Petrograd for 1915 still listed Aziber as the proprietor of the Preserves Factory on Staro-Petergofskii Prospect, indicating that he was alive at the time of the portrait. We can presume, however, that news of his death reached the editors of Ves' Petrograd only after substantial delay.

See Isakov, Filonov, No. 35.

Petrowa, Harten, Pawel Filonow und seine Schule, p. 40.

P. Filonov: 'Proshenie v Sovet professorov Vysshego Khudozhestvennogo uchilishcha ot vol'noslushatelia, Pavla Nikolaevicha Filonova', 1910 [Petition Addressed to the Council of Porfessors, Higher Art Institute (Imperial Academy of Arts), St. Petersburg from the Audior, P.N. Filonov, 1910]. Manuscript Department, Academy of Arts, St. Petersburg.

In conversations with the authors the late Evgenii Kovtun, one-time curator of Soviet graphics at the State Russian Museum in St. Petersburg, maintained that the child was Anatolii and not René, although he did not adduce documentary evidence.

Podmo, ‘Uncle Pania', p. 173.

Podmo affirmed that: 'Filonov, evidently, visited the St. Catherine Monastery in Jerusalem, and, under the impression of the image of the Great Martyr Catherine which he saw, he painted a wonderful icon of St. Catherine and gave it to his elder sister, Ekaterina. I saw this icon. It was amazing, just like an ancient Byzantine one-no bright colors, just brown and green tones.' (Podmo, 'Uncle Pania', p. 175). Additionally, see I. Pronina: 'Zhizneopisanie Pavla Filonova' in Bowlt, Misler, Pronina, Sarab'ianov, p. 27. Filonov visited the Holy Land three times.

The State Russian Museum possesses a drawing entitled Costantinople, dated 1907. The date of 1918 which Glebova furnishes in 'Dnevniki Filonova' (p. 153) is obviously a lapse of memory or a misprint.

See the original source: P. Filonov et al.: Intimnaia Masterskaia zhivopistsev' i risoval'shchikov 'Sdelannye kartiny', St. Petersburg, 1914, unpaginated.

P. Filonov: 'Proletarizatsiia izobrazitel'nogo iskusstva' in Bowlt, Misler, Pronina, Sarab'ianov, p. 165. English translation in (Misler and Bowlt 1983, p. 258).

P. Filonov: “Deklaratsiia 'Mirovogo rastsveta'” in Zhizn' iskusstva, Petrograd, 22 May 1923, No. 20, p. 14.

Discussing the establishment of a Museum of Modern and Contemporary Art, Filonov even proposed including a Department of Icons, an idea to which he returned even in the 1930s, See P. Filonov: "Polozhenie ob Institute issledovaniia sovremennogo izobrazitel'nogo iskusstva" in Bowlt, Misler, Pronina, Sarab'ianov, p. 117. English translation in (Misler and Bowlt 1983, p. 181). P. Filonov: 'Ya budu govorit" (ca. 1924) in Bowlt, Misler, Pronina, Sarab'ianov, p. 125. English translation in (Misler and Bowlt 1983, p. 225).

We would like to thank Yulia Solonovich of the State Russian Museum, St. Petersburg, for suggesting that Filonov had copied the icon of St. Catherine in the Cathedral of the Intercession in Rogozhskaia sloboda and for finding vintage photographic reproductions of the same.

Letter from Sister Gabriela, Orthodox nun and icon-painter, to John E. Bowlt dated 22 February 2021.

In his review of the 'Non-Partisan Exhibition' in St. Petersburg, 1913, to which Filonov contributed, Ieronimin Yasinsky referred to him as 'one of the Decadents'. See I. Yasinsky: "Vystavka vnepartiinykh" in Birzhevye vedomosti, St. Petersburg, 1913, 16 February, No. 13403, p. 4 (Evening Edition).

Filonov, 'Deklaratsiia 'Mirovogo rastsveta', p. 90. English translation in (Misler and Bowlt 1983, p. 170).

Filonov, 'Avtobiograficheskie teskty', p. 78. English translation in(Misler and Bowlt 1983, p. 122).

Report No. 168/12 dated 23 January, 2014, from the State Russian Museum, St. Petersburg, signed by A.B. Liubimova et al., and relayed to Mikhail Suslov, present owner of the icon.

Letters from Yulian Khalturin to Nicoletta Misler and John E. Bowlt from between 9 and 23 February 2021.

P. Filonov: 'Ideologiia analiticheskogo iskusstva' in Isakov, Filonov, p. 42. English translation in Bowlt (1988), p. 286.

Ibid.

See, for example, Snimki s drevnikh ikon, nakhodiashchikhsia v staroobriadcheskom Pokrovskom khrame pri Rogozhskom kladbishche (Moscow: Sherer and Nabgol'ts, 1899, p. 111). Vol. 2 (plate CCLXXI, item No. 500) of Nikolai Likhachev's fundamental Materialy dlia istorii russkogo ikonopisaniia (St. Petersburg: Department for the Preparation of State Papers, 1906) carries a black and white reproduction of the Stroganov icon in question where it is described as "St. Catherine, the Great Martyr, upright, with the depiction of certain events from her life". Other early reproductions can be found in A. Burtsev ed.: Muraveinik, khudozhestvennyi, bibliograficheskii i etnograficheskii sbornik, St. Petersburg, 1910, No. 9-10, p. 163; and his Dosugi. Khudozhestvenno-bibliograficheskii sbornik, St. Petersburg, 1911, No. 3. 


\section{References}

Bowlt, John, ed. 1988. Russian Avant-Garde. Theory and Criticism, 1902-1934. London: Thames and Hudson.

Bowlt, John, Nicoletta Misler, Irina Pronina, and Andrei Sarab'ianov, eds. 2006. Filonov. Khudozhnik, issledovatel', uchitel'. Moscow: Tomesh.

Ershov, Gleb. 2015. Pavel Filonov. Khudozhnik 'Mirovogo rastsveta'. St. Petersburg: European University.

Glebova, Evdokiia. 1984. Dnevniki Filonova v vospominaniiakh ego sestry, E.N. Glebovoi. In SSSR. Vnutrennie Protivorechiia. New York: Chalidze.

Gmurzynska, Krystyna, Nicoletta Misler, and John E. Bowlt. 1992. Die Physiologie der Malerei. Pawel Filonow in den 20er Jahren/The Physiology of Painting. Pavel Filonov in the 1920s. Cologne: Catalog of exhibition at Galerie Gmurzynska.

Isakov, Sergei. 1930. 'Introduction', Filonov. Leningrad: Catalogue of exhibition at the State Russian Museum.

Kovtun, Evgenii. 1988. Filonov. Leningrad: Catalogue of exhibition at the State Russian Museum, Avrora.

Kriż, Jan. 1966. Pavel Nikolaevič Filonov. Prague: Nakladetelstvi Československych Vytvarnich Umëlcu.

Lozovoi, Nikolai. 2005. 'Vospominaniia o Filonove'. Experiment 11: 269-86.

Misler, Nicoletta, and John Bowlt. 1983. Pavel Filonov. A Hero and His Fate. Austin: Silvergirl.

Misler, Nicoletta, John Bowlt, and Irina Men'shova, eds. 2005. Experiment. Los Angeles: Institute of Modern Russian Culture.

Petrova, Evgeniia. 2006. Pavel Filonov. Ochevidets Nezrimogo. St. Petersburg: Palace Editions.

Petrova, Evgeniia, ed. 2008. Pavel Filonov. Sbornik Statei. St. Petersburg: Palace Editions.

Petrowa, Ewgenija, and Jurgen Harten, eds. 1990. Filonow und seine Schule. Dusseldorf: Catalogue of Exhibition at the Kunsthalle.

Pravoverova, Liudmila. 2008. Pavel Filonov, Real'nost' i mif. Moscow: Agraf.

Pravoverova, Liudmila. 2020. Pavel Filonov. Analiticheskoe Iskusstvo. Sdelannye Kartiny. Moscow: Akademcheskii proekt.

Pronina, Irina. 2010. 'Shkola Filonova': Neizvestnye stranitsy istorii'. Russkoe Iskusstvo, 84-93.

Semina, Maiia. 2017. Pavel Filonov: biografiia i geografiia. Zolotaia Palitra, 6-13.

Sokolov, Mikhail. 2008. Pavel Filonov. Moscow: Art-Rodnik.

Stolbova, Ekaterina. 2012. Konservnaia imperiia Aziberov. Yunyi Kraeved, 6-14. 